\title{
Expression of Pheromone Binding Proteins During Antennal Development in the Gypsy Moth Lymantria dispar
}

\author{
R. G. Vogt, A. C. Köhne, a J. T. Dubnau, and G. D. Prestwich \\ Department of Chemistry, State University of New York at Stony Brook, Stony Brook, New York 11794
}

\begin{abstract}
We have identified 2 olfactory specific proteins in the gypsy moth Lymantria dispar that are uniquely associated with the male antennae, the principal olfactory organs of this animal. These proteins were the major soluble protein components of the olfactory sensilla, present in equivalent amounts. Both proteins comigrated on SDS-PAGE, showing an apparent molecular mass of $15,000 \mathrm{Da}$ but migrated separately on non-SDS-PAGE, indicating differences in net charge. $\mathrm{N}$-terminal amino acid sequence analysis showed that the 2 proteins share $50 \%$ identity, indicating that they are genetically distinct homologs. Both proteins bound the $L$. dispar sexpheromone, associated with antisera prepared against the previously identified pheromone-binding protein (PBP) of the moth Antheraea polyphemus, and shared sequence identity with the A. polyphemus PBP. These 2 proteins are therefore identified as $L$. dispar PBPs and are termed PBP, and PBP based on their migration differences on non-SDS-PAGE. It is estimated that $\mathrm{PBP}_{1}$ and $\mathrm{PBP}_{2}$ are present in the sensilla lumen at a combined concentration of $13.4 \mathrm{~mm}$.

The expression of the $L$. dispar PBPs was examined during the $11 \mathrm{~d}$ development of the adult antenna. $\mathrm{PBP}_{1}$ and $\mathrm{PBP}_{2}$ were first detected by non-SDS-PAGE analysis and Coomassie blue staining $3 \mathrm{~d}$ before adult eclosion, on day A-3. Levels increased, reaching a plateau on day A-1 that continued into adult life. In vivo labeling studies indicated that the rate of PBP synthesis increased from A-3 to a plateau on A-2, where it remained into adult life. In vitro translations of antennal mRNAs indicated that translatable PBP mRNA was available at a very low level on day $A-4$, increased slightly on A-3 and dramatically on A-2, and remained at a high level into adult life. PBP mRNA represented the major translatable mRNA in the antenna during this period. It was estimated that the PBPs undergo a combined steady-state turnover of $8 \times 10^{7} \mathrm{molecules} / \mathrm{hr} /$ sensillum. Cursory in vivo and in vitro translation studies of antennal mRNA from A. poly-
\end{abstract}

\footnotetext{
Received Dec. 21, 1988; revised Feb. 16, 1989; accepted Mar. 2, 1989.

We wish to thank Drs. L. M. Riddiford and R. Rybczynski and Ms. G. G. Vogt for many fruitful discussions, for encouragement, and for comments on the manuscript: Dr. J. H. Willis for helpful advice regarding protein sequencing; Dr. C. P. Schwalbe of the U.S. Department of Agriculture, APHIS, Otis Air Force Base MA, for supplying $L$. dispar larvae; and Drs. T. Gyorgyi and M. R. Lerner for supplying $M$. sexta tissue and $M$. sexta PBP antisera and sequence data.

This work was supported by U.S. Department of Agriculture competitive research grant (85-CRCR-11736) to G.D.P., and a student fellowship from Deutscher Akademischer Austauschdienst to A.C.K.

Correspondence should be addressed to Dr. Richard G. Vogt at his present address: Section of Molecular Neurobiology, Yale University School of Medicine, Tompkins 5, 333 Cedar Street, New Haven, CT 06510

a Present address: Max-Planck-Insitut für Biochemie, Martinsried, FRG.

Copyright (c) 1989 Society for Neuroscience $0270-6474 / 89 / 093332-15 \$ 02.00 / 0$
}

phemus and Manduca sexta showed similar temporal patterns of PBP expression, suggesting that the $L$. dispar observations are general.

Terrestrial animals detect odorants with sensory dendrites bathed in an aqueous medium. However, most airborne odorants are hydrophobic molecules and thus do not rapidly partition into an aqueous medium. Both invertebrate and vertebrate animals appear to have adapted to this situation by evolving odorant binding proteins to aid in odorant capture. Odorant binding proteins have been isolated and characterized from the olfactory organs of insects (Vogt and Riddiford, 1981a, b; Gyorgyi et al., 1988), cows (Pelosi et al., 1982; Pevsner et al., 1985), rats (Pevsner et al., 1986), and frogs (Lee et al., 1987). A potentially analogous proteinaceous fluid has also been described in a land snail (Chase and Tolloczko, 1985; Chase, 1986). Odorant binding proteins are (1) small, water soluble, and extracellular proteins that (2) are located in the fluid surrounding the sensory dendrite and (3) bind odorants (Vogt and Riddiford, 1981b; Pelosi et al., 1982; Pevsner et al., 1985). The odorant binding proteins are thought to enhance the capture rate of hydrophobic odorants by (1) helping to solubilize these odor molecules, thus enhancing their partitioning into the aqueous fluid surrounding the dendrites and (2) then aiding in the transport of the odorants to receptor proteins located in the dendrite membrane (Vogt et al., 1985; Vogt, 1987; Pevsner et al., 1988a).

A pheromone binding protein (PBP) was first described from the male antennae of the wild silkmoth Antheraea polyphemus (Vogt and Riddiford, 1981a, b). This 15,000 Da protein was both sex and tissue specific in its location. The protein was extracellular and was located in the sensillum lumen surrounding the sensory dendrites (Fig. 1) at an estimated concentration of $10 \mathrm{~mm}$ (Vogt and Riddiford, 1981b; Klein, 1987). There is evidence that this PBP may exist in vivo as a $30,000 \mathrm{Da}$ dimer (de Kramer and Hemberger, 1987). Sex pheromone was shown to associate with the $A$. polyphemus PBP (Vogt and Riddiford, $1981 \mathrm{~b}$; Vogt et al., 1988), and although this association appeared to be weak (Vogt and Riddiford, 1986; Vogt, 1987), it also appeared to be relatively specific in nature (de Kramer and Hcmbcrgcr, 1987). Recently, an antennal protein from the tobacco hawk moth Manduca sexta has been identified as a PBP based on its (1) sequence homology to the $A$. polyphemus PBP, (2) tissue specificity, and (3) association with the olfactory sensilla (Gyorgyi et al., 1988). A full-length amino acid sequence of the $M$. sexta PBP was indirectly obtained through cDNA cloning techniques and DNA sequencing (Gyorgyi et al., 1988). The $M$. sexta PBP was first expressed late in adult development. However, unlike the $A$. polyphemus PBP, the $M$. sexta PBP was 
cxpressed in female as well as male antennae, but at relatively low levels (Gyorgyi et al., 1988).

This paper describes the pheromone binding proteins of the gypsy moth Lymantria dispar. Since $L$. dispar was accidentally introduced to North America in 1869 at Medford, Massachusetts (Forbush and Fernald, 1896), it has proven a very tenacious pest, defying almost all attempts to control it in the Northeastern region of the United States. The females are too heavy to fly due to their production of a very large mass of eggs and have very reduced antennae. In contrast, the males are very active fliers and possess 2 large antennae each with about 22,000 pheromone-sensitive sensilla measuring ca. $200 \mu \mathrm{m}$ in length and 5 $\mu \mathrm{m}$ in diameter (Scheffler, 1975; Schneider et al., 1977). The sensilla are essentially identical repeats, each containing 2 sensory neurons (Fig. 1) (Schneider et al., 1977). The females attract males with a single-component pheromone (7R,8S)-7,8-epoxy2-methyloctadecane, commonly termed (+)disparlure (Bierl et al., 1970; Prestwich et al., 1989). However, only one of the pair of sensory neurons responds specifically to this (+)optical enantiomer (Hansen, 1984). The second neuron has been shown to respond specifically to the corresponding (-) optical enantiomer, although this $(-)$ enantiomer is not a component of the $L$. dispar pheromone (Hansen, 1984). However, the $(-)$ enantiomer is released by the sibling species Lymantria monacha (Hansen, 1984), which cohabits with L. dispar (South, 1907), and this compound has been shown to modify $L$. dispar behavior in a specific manner (Preiss and Kramer, 1983).

In this paper we identify $2 L$. dispar proteins as PBPs and describe their expression during the development of the male antenna. We also compare $L$. dispar PBP expression with PBP expression in $A$. polyphemus and $M$. sexta. Although PBPs were originally described in $A$. polyphemus, $L$. dispar was chosen for these studies because this species is much easier to raise in the laboratory and is thus more amenable to developmental studies. Furthermore, the high degree of sensory specificity of the male $L$. dispar antenna makes this tissue ideal for the study of biochemical and molecular biological mechanisms that underlie olfactory function.

\section{Materials and Methods}

Animals and tissue collection. L. dispar (Lepidoptera: Lymantriidae) were obtained as larvae already on artificial diet from APHIS, USDA Otis Air Force Base, MA, courtesy of Dr. C. P. Schwalbe. Animals were then raised at $27^{\circ} \mathrm{C}$ on a $16: 8 \mathrm{~L}: \mathrm{D}$ cycle. Lights off was at $2200 \mathrm{hr}$. $A$. polyphemus (Lepidoptera, Saturniidae) were obtained as pupae from either H. W. Hartman (Elkhorn, IN) or D. Bantz (Caledonia, WI) and stored at $4^{\circ} \mathrm{C}$ until use. To initiate development, $A$. polyphemus pupae were incubated at $27^{\circ} \mathrm{C}$ on a 16:8 L:D cycle. Manduca sexta (Lepidoptera: Sphingidae) male antennae were provided frozen courtesy of Drs. T. Gyorgyi and M. R. Lerner. All tissues were frozen in $1.5 \mathrm{ml}$ microcentrifuge tubes in liquid nitrogen (LN) immediately following dissection and subsequently stored at $-90^{\circ} \mathrm{C}$ until use.

Animals used in developmental studies were selected as prepupae by a characteristic immobility and a dorsal to ventral bending. Selection was done between 1700 and $2200 \mathrm{hr}$. Greater than $95 \%$ of those animals selected as prepupae during these times were fully tanned pupae $24 \mathrm{hr}$ later. Individuals not fully tanned at this time were discarded. At the appropriate age, antennae were dissected, frozen, and stored. Individuals were staged at the time of dissection according to visual criteria described in Figure 5.

Tissue preparation. Tissues used for all electrophoretic studies were first lyophilized and then homogenized by hand in $10 \mathrm{mM}$ Tris- $\mathrm{HCl}(\mathrm{pH}$ 7.0 ) in a small ground glass homogenizer held in ice/water. Homogenates were centrifuged $\left(5 \mathrm{~min}, 12,000 \times g, 4^{\circ} \mathrm{C}\right)$, and the supernatants were removed, transferred to microcentrifuge tubes, and frozen in $\mathrm{LN}$. These were then lyophilized, dissolved in an appropriate volume of $\mathrm{npH}_{2} \mathrm{O}$ (NanoPure water filtration system, Barnstead) followed by an equal

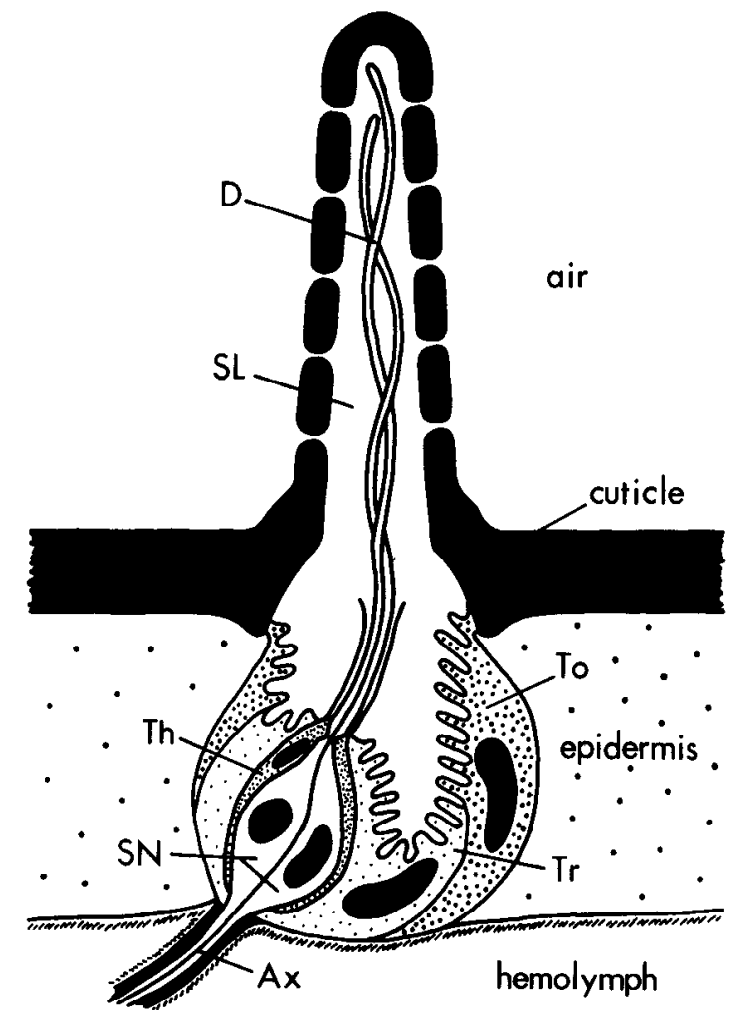

Figure 1. Schematic of a pheromone-sensitive sensillum. The cell bodies of the sensory neurons $(S N)$ reside at the base of the sensillum, surrounded concentrically by the thecogen $(T h)$, trichogen $(T r)$, and tormogen $(T o)$ accessory cells. Dendrites $(D)$ project into the sensillum lumen $(S L)$, which is filled with fluid containing PBP. Axons $(A x)$ project to the brain. (Redrawn after Steinbrecht, 1987.)

volume of appropriate $2 \times$ electrophoresis sample buffer. Sample buffer $(2 \times)$ for non-SDS gels was $100 \mathrm{~mm}$ Tris- $\mathrm{HCl}(\mathrm{pH} 6.8), 20 \%$ glycerol, $0.005 \%$ bromphenol blue (BPB). Sample buffer $(2 \times)$ for SDS gels was $125 \mathrm{~mm}$ Tris- $\mathrm{HCl}$ (pH 6.8), 20\% glycerol, 4\% SDS, $10 \%$ mercaptoethanol, $0.005 \%$ BPB.

Sensilla isolation. Sensilla were isolated from adult male antennae as described previously (Vogt, 1987), modified after Klein and Keil (1984). Branches of 40 antennae were combined with $4 \mathrm{ml}$ of glass beads $(0.1-$ $0.5 \mathrm{~mm}$ diameter) in a $15 \mathrm{ml}$ Corex tube, chilled in $\mathrm{LN}$, and then shaken violently for about $3 \mathrm{sec}$ on a vortex mixer. The tube and contents were lyophilized, and the contents were transferred to a glass petri dish. The sensilla adhered to the glass surface while the rest was shaken away. The sensilla were scrapped from the glass and transferred to a microcentrifuge tube for storage at $-90^{\circ} \mathrm{C}$. This procedure yielded about 0.5 mg lyophilized sensilla per 100 antennae. Sensilla homogenates were prepared by homogenizing lyophilized sensilla in a ground glass homogenizer, as described above under Tissue Preparation. Following centrifugation at $12,000 \times g$ for $5 \mathrm{~min}$, the resulting supernatant was used for protein determination and electrophoretic studies.

Determination of sensilla protein concentration. The total protein content of the supernatant of isolated sensory hair was measured using the BCA assay (Pierce Chemical Company, Rockford, IL) with BSA as the protein standard.

Electrophoresis. All protein separations were done using non-SDS (nondenaturing) or SDS (denaturing)-PAGE. Recipes were after Laemmli (1970) and Ames (1974). For non-SDS gels, the SDS was replaced with $\mathrm{npH}_{2} \mathrm{O}$. Non-SDS gels were run in a $4^{\circ} \mathrm{C}$ cold cabinet. SDS gels were run at room temperature. Molecular-wcight markcrs for SDS gels were either BioRad low-molecular-weight markers or Amersham ${ }^{14} \mathrm{C}$ labeled Rainbow markers. For general protein visualization, gels were stained in $0.25 \%$ Coomassie blue R-250 in $50 \%$ methanol (MeOH), $10 \%$ acetic acid.

For fluorography of ${ }^{35} \mathrm{~S}$-methionine-labeled proteins, gels were soaked $15 \mathrm{~min}$ in $100 \%$ glacial acetic acid, $60 \mathrm{~min}$ in 10\% PPO (Sigma) in glacial acetic acid, $15 \mathrm{~min}$ in $\mathrm{npH}_{2} \mathrm{O}$, and dried onto paper under heat 
and vacuum. Dried gels were exposed to preflashed XAR5 X-Ray film (Kodak) at $-90^{\circ} \mathrm{C}$ for an appropriate time.

For immunoblots, proteins were transferred from non-SDS polyacrylamide gels to nitrocellulose (NC) (BioRad) in $25 \mathrm{~mm}$ Tris base, 192 mM glycine in $20 \% \mathrm{MeOH}$ at $70 \mathrm{~V}, 4^{\circ} \mathrm{C}$ for up to $12 \mathrm{hr}$ (Towbin et al., 1979). Following transfer, $\mathrm{NC}$ was blocked $12 \mathrm{hr}$ at room temperature in $10 \%$ nonfat dry milk (NFDM) in PBS-T (2.5 mM NaH $\mathrm{NO}_{4}, 7.9 \mathrm{~mm}$ $\mathrm{Na}_{2} \mathrm{HPO}_{4}, 150 \mathrm{~mm} \mathrm{NaCl}$ containing $0.05 \%$ Tween 20 detergent). Blocked NC was incubated with primary antisera in PBS-T at indicated dilution. Bound primary antibody was visualized using the Vectastain $A B C$ peroxidase kit (Vector Laboratories). The peroxidase reaction was carried out in a solution containing $2 \mathrm{ml} 4$-chloro-1-naphthol $(3 \mathrm{mg} / \mathrm{ml}$ in $\mathrm{MeOH})$ and $5 \mu \mathrm{l} \mathrm{H}_{2} \mathrm{O}_{2}(30 \%)$ per $10 \mathrm{ml}$ PBS-T.

$\mathrm{N}$-terminal amino acid sequencing. Proteins were electrophoretically purified by non-SDS-PAGE and transferred directly to modified glass fiber filters (Whatman GF/C, soaked in neat trifluoroacetic acid $60 \mathrm{~min}$ and air-dried) following a procedure modified after Aebersold et al. (1986) in which NP40 was omitted from all steps. Transfer was in $1 \%$ glacial acetic acid in $\mathrm{npH}_{2} \mathrm{O}$ at $70 \mathrm{~V}, 4^{\circ} \mathrm{C}$ for $12 \mathrm{hr}$. Proteins were visualized using Coomassie blue staining (Aebersold et al., 1986). The blots were dried under vacuum, and the protein bands of interest cut out and stored in sealed microcentrifuge tubes at $-90^{\circ} \mathrm{C}$ until sequencing.

Amino terminal sequences were obtained directly from protein bound to the glass fiber filters. Sequencing was performed by Mr. Thomas Fisher, using an Applied Biosystems $470 \mathrm{~A}$ protein sequencer at the State University of New York at Stony Brook Center for Analysis and Synthesis of Macromolecules. An earlier version of the $A$. polyphemus sequence appeared in Vogt and Prestwich (1987), and a partial sequence of one of the $L$. dispar proteins appeared in Vogt (1987). The sequences presented here are based on 6 independent samples of the $A$. polyphemus PBP and on 2 independent samples of each of the $L$. dispar PBPs. The $M$. sexta sequence presented in Figure 4 was kindly provided by Drs. T. Gyorgyi and M. R. Lerner (Gyorgyi et al., 1988).

Radiolabeled pheromone. Both enantiomers of disparlure were prepared at high specific activity $(58 \mathrm{Ci} / \mathrm{mmol})$ by homogeneous tritiation of the optically active alkenyl oxiranes, as described elsewhere (Prestwich et al., 1989). Storage solutions were maintained in $1: 1$ heptane: toluene at $-20^{\circ} \mathrm{C}$ (Prestwich, 1987). Ethanol (EtOH) stock solutions were prepared by drying an aliquot of the heptane-toluene solution under $\mathrm{N}_{2}$, then dissolving in $\mathrm{EtOH}$, and finally diluting in $\mathrm{EtOH}$ to $10^{-4}$ and $10^{-5} \mathrm{M}$ stocks, respectively.

${ }^{3} \mathrm{H}$-disparlure binding study. The binding of labeled disparlure to PBP was examined by non-SDS-PAGE of a sensilla extract solution containing ${ }^{3} \mathrm{H}$-disparlure. Lyophilized sensory hairs $(0.65 \mathrm{mg})$ were homogenized in $300 \mu$ of non-SDS $1 \times$ electrophoresis sample buffer and centrifuged $(5 \mathrm{~min}, 12,000 \times \mathrm{g}$ ). This preparation was shown not to degrade either $(+)$ or $(-)$ disparlure over the time course of $1 \mathrm{hr}$, when analyzed by thin-layer chromatography (R. G. Vogt, unpublished observations). Sensilla supernatant was distributed to 6 borosilicate tubes $(10 \times 75 \mathrm{~mm}), 45 \mu \mathrm{l} /$ tube, with the tubes held in crushed ice. Each tube contained $5 \mu \mathrm{g}$ total protein. At $t_{0}, 1 \mu \mathrm{l}$ of either $(+)$ or $(-)^{3} \mathrm{H}$-disparlure from EtOH stocks (see above) was added to each tube. Tubes were mixed briefly on a vortex mixer and returned to the ice. After $5 \mathrm{~min}$ incubation, $30 \mu 1$ of each incubation was loaded onto a $15 \%$ non-SDS gel and electrophoresed. Immediately following electrophoresis, the gel was fixed in $7 \%$ formaldehyde ( $30 \mathrm{~min}$ ), soaked in $1 \mathrm{M}$ salicylic acid ( $\mathrm{Na}^{+}$-salt) for $1 \mathrm{hr}$ (Chamberlain, 1979), and air-dried (room temp.) overnight between 2 sheets of cellophane clamped to a glass plate. The gel was then exposed to preflashed XAR5 X-Ray film (Kodak) at $-90^{\circ} \mathrm{C}$.

Production of polyclonal antisera. Antisera to the PBP of $A$. polyphemus was prepared as previously described (Vogt, 1984). A centrifuged homogenate of 100 male antennae $(10 \mathrm{mM}$ Tris- $\mathrm{HCl}, \mathrm{pH} 7.0)$ was concentrated to $5 \mathrm{ml}$ by vacuum dialysis (Pro-di-Con, Bio Molecular Dynamics). PBP was purified from this using preparative non-SDS-PAGE. The cdges of the gel were sliced and stained to localize the PBP region, which was then removed and homogenized by passage through syringe needles ( 23 gauge), using Tris- $\mathrm{HCl}(10 \mathrm{mM}, \mathrm{pH} 7.0)$ as a lubricant. The gel slurry was mixed 1:1 with Freund's complete adjuvant (Sigma, 20 $\mathrm{ml}$ final volume) and stored in $1 \mathrm{ml}$ aliquots at $-20^{\circ} \mathrm{C}$. Two milliliters were injected subcutaneously into the backs of 2 Rex rabbits on a biweekly schedule for 8 weeks. Serum was collected from a peripheral ear vein.

Antisera were prepared separately against both $\mathrm{PBP}_{1}$ and $\mathrm{PBP}_{2}$ of $L$. dispar. Two thousand male antennae were collected from newly emerged adults, frozen in $\mathrm{LN}$, and stored at $-90^{\circ} \mathrm{C}$. These were lyophilized and then homogenized (BioSpec) in $50 \mathrm{ml}$ Tris- $\mathrm{HCl}(10 \mathrm{~mm}, \mathrm{pH} 7.0)$ in 15 $\mathrm{ml}$ Corex tubes in ice/water. The centrifuged supernatant $(10,000 \mathrm{rpm}$, Beckman SW50 rotor, $4^{\circ} \mathrm{C}, 10 \mathrm{~min}$ ) was concentration by lyophilization, redissolved in $6 \mathrm{ml}$ of non-SDS sample buffer $(1 \times)$, and electrophoresed through a $7.5 \%$ non-SDS preparative polyacrylamide gel $(4.2 \mathrm{~mm} \times 10$ $\mathrm{cm}$ cross section, $100 \mathrm{~mA}$ constant current, $4^{\circ} \mathrm{C}$ ). The acrylamide at the dye front, containing the PBPs, was excised and laid onto a $15 \%$ nonSDS preparative gel $(5 \mathrm{~mm} \times 10 \mathrm{~cm}$ cross section). Following electrophoresis $\left(100 \mathrm{~mA}\right.$ constant current, $\left.4^{\circ} \mathrm{C}\right)$, the edges of this gel were removed and stained with Coomassie blue to locate $\mathrm{PBP}_{1}$ and $\mathrm{PBP}_{2}$. The corresponding gel sections were excised and homogenized separately by passage through syringe needles ( 23 gauge) in $\mathrm{npH}_{2} \mathrm{O}$ to a final volume of $10 \mathrm{ml}$ each, and stored at $-90^{\circ} \mathrm{C}$. The protein purity was assessed by non-SDS-PAGE (15\%), which showed that each PBP was contaminated by about a $10 \%$ level by the other PBP, but was otherwise electrophoretically pure. $\mathrm{PBP}_{1}$ and $\mathrm{PBP}_{2}$ gel slurries were respectively injected subcutaneously into the backs of 2 New Zealand White rabbits on a $10 \mathrm{~d}$ schedule. The first injections were $2 \mathrm{ml}$ each, consisting of $50 \%$ Freund's complete adjuvant (Sigma). Subsequent injections were $2 \mathrm{ml}$ of gel slurry only. Serum was collected by cardiac puncture.

In vivo labeling of antennal proteins. ${ }^{35} \mathrm{~S}-\mathrm{methionine}\left(\mathrm{Tran}^{35} \mathrm{~S}-\mathrm{Label}\right.$, ICN) was diluted $1: 2$ with insect saline $(5.2 \mathrm{mM} \mathrm{NaCl}, 26.8 \mathrm{~mm} \mathrm{KCl}$, $12.9 \mathrm{mM} \mathrm{MgCl}_{2}, 1.25 \mathrm{mM} \mathrm{KHCO}_{3}, 1.25 \mathrm{mM} \mathrm{KH}_{2} \mathrm{PO}_{4}, 1.35 \mathrm{mM} \mathrm{CaCl}_{2}$, $166 \mathrm{~mm}$ glucose). Ten microliters ( $33 \mu \mathrm{Ci}$ ) was injected into the heads of pupae and adults using a Hamilton syringe ( $50 \mu 1,30$ gauge needle). The injection was made between and just forward of the antennal attachment sites, and the injection hole did not require sealing. Tissues were prepared as described above.

Purification of total antennal RNA. RNA purification was modified from a protocol previously used to isolate RNA from insect integument (Riddiford, 1982). Antennae were frozen in $\mathrm{LN}$ immediately following removal from the animal and stored at $-90^{\circ} \mathrm{C}$. Frozen antennae were homogenized in a lysis buffer containing $6 \mathrm{~m}$ urea, $69 \mathrm{~mm}$ SDS, $35 \mathrm{~mm}$ $\mathrm{NaCl}, 0.1 \mathrm{~mm}$ EDTA, $1 \mathrm{~mm}$ Tris-HCl, pH 8.0. Following phenol/chloroform extraction, the RNA was collected by $\mathrm{CsCl}$ density-gradient centrifugation (Maniatis et al., 1982). Following EtOH precipitation, the RNA was stored in either $70 \% \mathrm{EtOH}$ or $\mathrm{npH}_{2} \mathrm{O}$ at $-90^{\circ} \mathrm{C}$ until use. This procedure yielded ca. $150 \mu \mathrm{g}$ total RNA $\left(1 \mathrm{OD}_{260}\right.$ unit $=40 \mu \mathrm{g}$ total RNA) per 100 adult male $L$. dispar antennae ( $90 \mathrm{mg}$ wet tissue). The quality of the RNA (ca. $5 \mu \mathrm{g}$ ) was routinely assessed at the end of each isolation by $1 \%$ nondenaturing agarose gel electrophoresis in the presence of ethidium bromide (Maniatis et al., 1982) and by in vitro translation (IVT).

IVTs and immunoprecipitations. IVTs of total RNA were performed using a rabbit reticulocyte lysate kit (ProMega) in the presence of RNasin (placental, ProMega) and ${ }^{35}$ S-methionine (Tran ${ }^{35}$ S-Label, ICN), following protocols supplied (15-45 $\mu \mathrm{g}$ total RNA per reaction). Total reaction volume was $50 \mu \mathrm{l}$. At the end of the reaction $\left(1 \mathrm{hr}, 30^{\circ} \mathrm{C}\right) 10 \mu \mathrm{l}$ was mixed with $20 \mu \mathrm{lnpH} \mathrm{np}_{2} \mathrm{O}$ and $20 \mu \mathrm{l} 2 \times$ SDS-sample buffer, boilcd 5 min, and stored at $-90^{\circ} \mathrm{C}$ for electrophoretic analysis of the total IVT mixture.

Immunoprecipitations were done using Protein A-Sepharose (PA-S) (Pharmacia) immediately following the translation reaction. PA-S (1 mg per sample to be precipitated) was suspended in $1 \mathrm{ml}$ PBSE-NP40 ( $25 \mathrm{~mm} \mathrm{~K}_{2} \mathrm{HPO}_{4}, 100 \mathrm{mM} \mathrm{NaCl}, 100 \mathrm{mM}$ EDTA, pH 7.6, 0.25\% NP40 detergent). Following 30 min incubation on ice, the PA-S was washed several times until the milk was visibly gone, and the final volume was adjusted to $20 \mu \mathrm{l} / \mathrm{mg}$ PA-S with PBSE-NP40.

Immunoprecipitations were initiated by combining $20 \mu \mathrm{l}$ of an IVT sample with $80 \mu \mathrm{l}$ PBSE-NP40 and $50 \mu \mathrm{l}$ of a 1:20 dilution of desired antisera. Following $30 \mathrm{~min}$ incubation on ice, $20 \mu \mathrm{l} \mathrm{PA-S}(1 \mathrm{mg} / \mathrm{ml})$ was added. Following an additional $30 \mathrm{~min}$ incubation on ice, the mixture was centrifuged $\left(3 \mathrm{~min}, 12,000 \times g, 4^{\circ} \mathrm{C}\right)$, and the pellet washed 4 times with PBSE-NP40. The final pellet was frozen, lyophilized, and dissolved in $40 \mu \mathrm{lnpH} \mathrm{n}_{2} \mathrm{O}$ followed by addition of $40 \mu \mathrm{l}$ of $2 \times$ SDSsample buffer. This was boiled $5 \mathrm{~min}$ and stored at $-90^{\circ} \mathrm{C}$. Total translated and immunoprecipitated proteins were examined on $15 \%$ SDS polyacrylamide slab gels which were subsequently fluorographed as described above.

\section{Results}

Identification of L. dispar PBPS

The $L$. dispar sex pheromone is detected by sensillae (Fig. 1) arrayed along the branches of the male antennae. Non-SDS 
a.

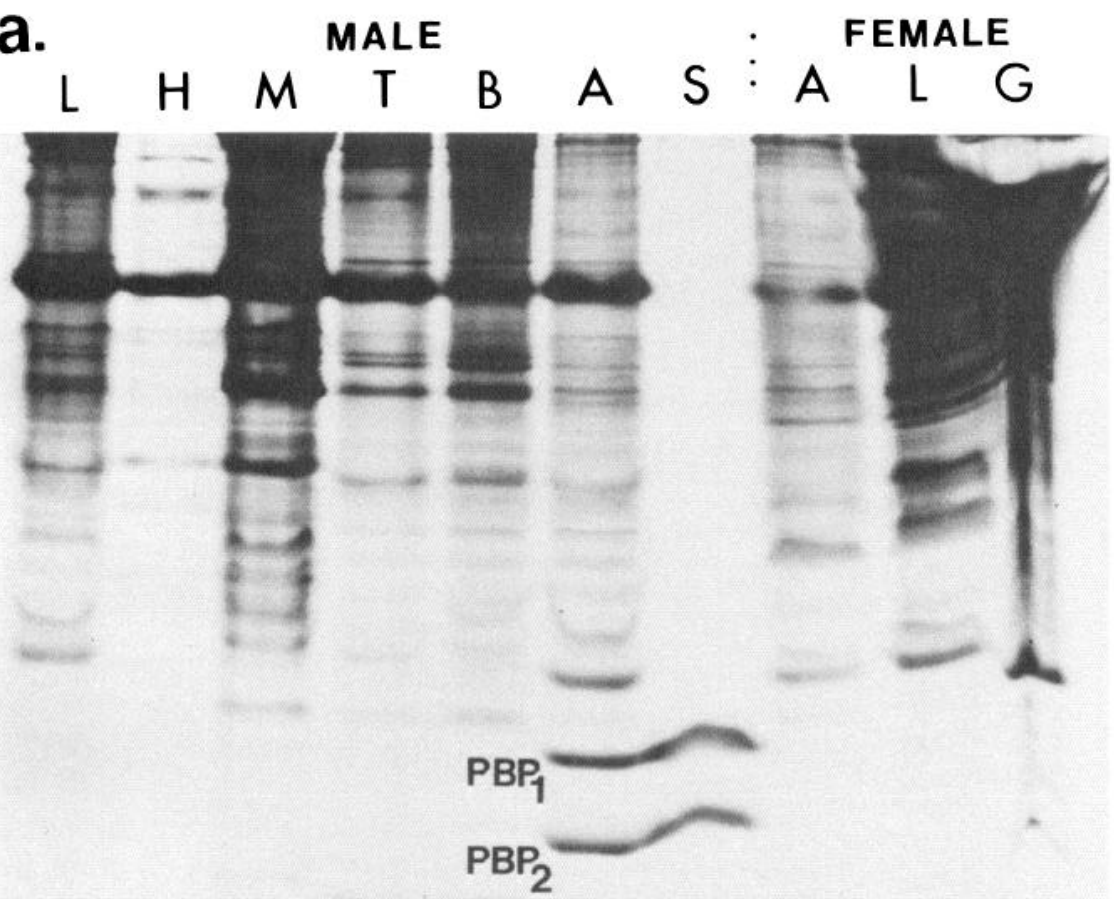

b.
Figure 2. Electrophoretic comparison of male and female $L$. dispar tissues, with proteins visualized by Coomassie blue staining $(a)$ and immunostaining (b). Tissue homogenates were divided between 2 gels, which received $75 \%(a)$ and $25 \%(b)$ of each sample, respectively. Antiserum used in the immunoblot $(b)$ was generated against the $A$. polyphemus $\mathrm{PBP}$ and used at a dilution of 1:200. Tissues and amounts represented in the total homogenates were from left to right: $L, 11$ male legs; $H, 2$ $\mu \mathrm{l}$ of male hemolymph; $M$, dorsal longitudinal muscles from 5 males; $T, 8.5$ male thoracic ganglia; $B, 8$ male brains; $A, 5$ male antennae; $S, 0.25 \mathrm{mg}$ male sensilla; $A, 18.5$ female antennae; $G, 6$ female abdominal tips which include the pheromone-producing glands. The apparent difference in mobility in the PBP bands in lanes $A$ and $S$ was due to different amounts of total protein in the respective lanes and not to differences in the proteins, indicated by the fact that the bands join at the lane boundaries. Protein separation was by nonSDS-PAGE (15\%).
(nondenaturing)-PAGE analysis of sensilla extracts revealed 2 prominent protein bands that were uniquely associated with male antennae (Fig. 2a). Both proteins reacted strongly with antisera prepared against the PBP of $A$. polyphemus (Fig. $2 b$ ). SDS-PAGE analysis of sensilla extracts showed only a single major protein band with an apparent molecular mass of 15,000
$\mathrm{Da}$ (data not shown, but see Fig. 8). Furthermore, both (+) and $(-)$ disparlure associated with both proteins, remaining so through electrophoretic separation, and showed a higher degree of association with the faster-migrating (lower) protein (Fig. 3). Thus, the 2 major sensilla proteins satisfy the criteria used to identify the A. polyphemus PBP (Vogt and Riddiford, 1981b). They (1) 


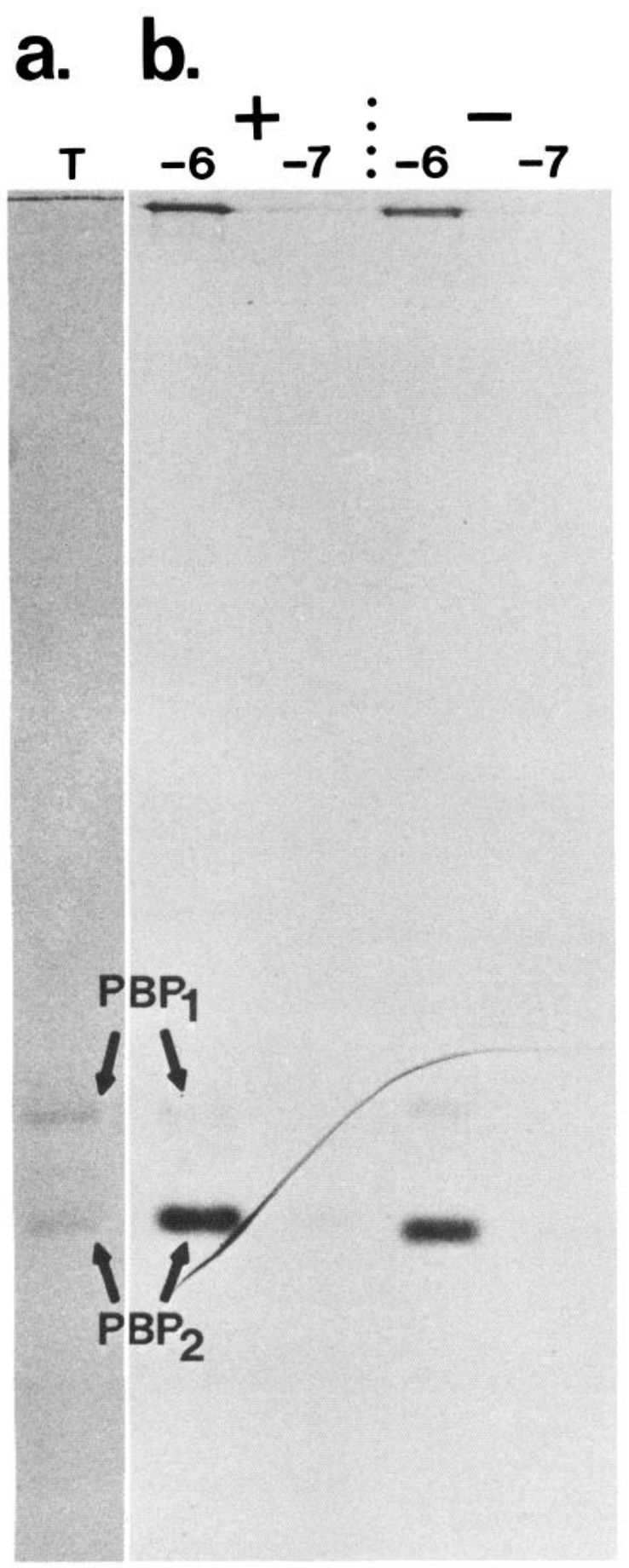

Figure 3. Electrophoretic demonstration of ${ }^{3} \mathrm{H}$-disparlure binding to PBPs. Homogenates of $L$. dispar sensilla were incubated with the $(+)$ and (-)enantiomers of ${ }^{3} \mathrm{H}$-disparlure, and then electrophoresed. $a(T)$, Coomassie blue-stained lane of one of these samples, showing the relative amounts and positions of $\mathrm{PBP}_{1}$ and $\mathrm{PBP}_{2} . b$, Fluorograph showing the $(+)$ and $\left(-\right.$ enantiomers of ${ }^{3} \mathrm{H}$-disparlure associating with $\mathrm{PBP}_{1}$ and $\mathrm{PBP}_{2}$. The disparlure concentrations were $10^{-6} \mathrm{M}(-6)$ and $10^{-7} \mathrm{M}(-7)$. The PBP concentration was $7 \times 10^{-6} \mathrm{M}$ throughout. Amounts of radioactivity loaded per sample from left to right were $0.73,0.05,0.43$, and $0.04 \mu \mathrm{Ci}$, respectively, based on measurement of a $3 \mu \mathrm{l}$ aliquot by liquid-scintillation counting. The amount of bound radioactivity was not measured. Protein separation was by non-SDS-PAGE (15\%). are uniquely associated with the male antennae, (2) are abundant soluble components of the pheromone sensitive sensilla, and (3) bind pheromones. We therefore identify these new proteins as PBPs, with the slower (upper) protein identified as $\mathrm{PBP}_{1}$ and the faster (lower) protein identified as $\mathrm{PBP}_{2}$, as characterized by non-SDS-PAGE. The concentration of total protein in sensilla extracts was measured to be $45 \mu \mathrm{g} / \mathrm{mg}$ lyophilized sensilla. Based on the Coomassie blue staining pattern of sensilla homogenate in Figure $2 a$, this measurement represents the combined PBP concentration in $L$. dispar sensilla.

$N$-terminal amino acid sequences were obtained for $\mathrm{PBP}_{1}$ and $\mathrm{PBP}_{2}$ of $L$. dispar and for the PBP of A. polyphemus. The first $30 \mathrm{~N}$-terminal amino acids are compared in Figure 4, along with the same region of the PBP of $M$. sexta (Gyorgyi et al., 1988). The regions shown represent ca. $20 \%$ of the full length of these proteins. Like the $L$. dispar PBPs, the PBPs of $A$. polyphemus and $M$. sexta have molecular masses of ca. $15,000 \mathrm{Da}$, and the $M$. sexta PBP has a predicted size of 142 amino acids based on its cDNA-derived full-length sequence (Vogt and Riddiford, 1981b; Gyorgyi et al., 1988). Table 1 summarizes the degree of identity between these 4 PBPs. Positions 1, 5, 12, 14, 22, and 27 are conserved in all 4 proteins. An amino acid appears at least twice within the group at every other position except positions 9 and 18 , and the majority of the amino acid differences represent conservative changes on the basis of property (e.g., hydrophobicity). The $2 \mathrm{~L}$. dispar proteins, while not the same gene product, sharing only $50 \%$ identity, are nevertheless clearly homologs, as is the entire group (Doolittle, 1986). Thus, in stark contrast to A. polyphemus and $M$. sexta, which possess only a single PBP species, respectively, $L$. dispar possesses 2 distinctly different PBPs.

\section{Developmental staging of $\mathrm{L}$. dispar}

In order to examine the time course of PBP expression, it was first necessary to establish criteria for staging the animals in their development. Adult development occurs during the pupal stage. Larval animals were initially selected as prepupae by a characteristic immobility and a dorsal to ventral bending. Greater than $95 \%$ of these animals were fully tanned pupae $24 \mathrm{hr}$ later. The day of pupation was counted as pupal day 0 , or P0. The day of prepupal selection was counted as P-1, and the days following pupation were P1, P2, P3, etc. Of a group of 237 males selected as prepupae, $38 \%$ eclosed as adults on $\mathrm{P} 10,60 \%$ on $\mathrm{P} 11$, and $2 \%$ on P12.

This asynchrony in development relative to $\mathrm{P} 0$ was not acceptable for determining the time of events occurring late in adult development. Instead, we utilized changing pigmentation patterns in wings and antennae to stage developing adults relative to the day of adult eclosion (A0). The staging criteria are illustrated in Figure 5. Similar criteria have been used to accurately stage preadult $M$. sexta (Schwartz and Truman, 1983). Days preceding adult eclosion were counted as A-1, A-2, A-3, etc., and the days following were $\mathrm{A} 1, \mathrm{~A} 2, \mathrm{~A} 3$, etc. In the following studies we examined tissues ranging from stage A-5 to A1.

\section{Developmental expression of $\mathrm{L}$. dispar PBPS}

$\mathrm{PBP}_{1}$ and $\mathrm{PBP}_{2}$ were first detectable in homogenates of A-3 antennae analyzed by both Coomassie blue staining and immunoreactivity following non-SDS-PAGE (Fig. 6). The amounts of both proteins had increased to adult levels $2 \mathrm{~d}$ later, on A-1. $\mathrm{PBP}_{2}$ appeared fainter than $\mathrm{PBP}_{1}$ in this immunoblot (Fig. 
LdisPBP1N-Ser Lys Glu Val Met Lys Gln Met Thr Ile Asn Phe Ala Lys Pro Met Glu Ala Cys Lys Gln Glu Leu Asn Val Pro Asp Ala Val Val LdisPBPZN-Ser Lys Asp Val Met His Gln Met Ala Leu Lys Phe Gly Lys Pro Ile Lys Leu Leu Gln Gln Glu Leu Gly Ala Asp Asp Ser Val Val ApolPBP N-Ser Pro Glu Ile Met Lys Asn Leu Ser Asn Asn Phe Gly Lys Ala Met Asp Gln Ser Lys Asp Glu Leu Ser Leu Pro Asp Ser Val Val MsexPBP N-Ser Pro Asp Val Met Lys Asn Leu Cys Leu Asn Phe Gly Lys Ala Leu Asp Glu Cys Lys Ala Glu Met Asn Leu Ser Asp Ser Ile Lys

Figure 4. $\quad N$-terminal sequences of $L$. dispar $\mathrm{PBP}_{1}\left(\right.$ Ldisl) and $\mathrm{PBP}_{2}($ Ldis2), A. polyphemus PBP (Apol), and M. sexta PBP (Msex).

$6 b)$. This may reflect the fact that the antisera used in this blot were generated against the $A$. polyphemus $\mathrm{PBP}$, which shares less identity with $\mathrm{PBP}_{2}$ than with $\mathrm{PBP}_{1}$ (Table 1 ).

In vivo labeling studies showed that, while the level of both PBPs plateaued by A-1, the rate of PBP synthesis plateaued a day earlier on A-2, and remained at this level into the adult stage (Fig. 7). These features were indicated by both a constant level of Coomassie blue staining (Fig. 7a) and a constant level of ${ }^{35} \mathrm{~S}$-methionine incorporation (Fig. $7 b$ ) in the PBPs on and following days A-1 and A-2, respectively. A constant amount under constant synthesis suggests that the PBPs are under a constant rate of turnover. Change in the overall antennal protein pattern was slight and gradual from A-5 through A-1, with the notable exception of the PBPs. However, at adult eclosion (A0), several new protein bands appeared to be expressed. None of these represented a change in state of the PBPs, however, as the immunoblot pattern did not change at this pupal-adult transition.

Immunoprecipitations of in vitro translated $m R N A$ s isolated from different stages showed that translatable PBP mRNA was present at very low levels on A-4, increasing slightly on A-3, and then increasing dramatically on A-2 (Fig. 8). Translatable PBP mRNA remained abundant on $\mathrm{A}-1$ and $\mathrm{A} 0$. Furthermore, translated PBP was clearly observed in the total translated mixtures from A-3 to A0 (Fig. 8), suggesting that PBP mRNA is present in high abundance relative to the background of other mRNAs at these stages and that the turnover of PBP is occurring at a high rate. There was a difference in apparent molecular masses between the in vitro translated PBPs and metabolically in vivo labeled PBPs (Fig. 8). This difference in mass was around $2000 \mathrm{Da}$, which could correspond to the removal of a ca. 18 amino acid leader sequence during extracellular export of the proteins. A deduced leader sequence of 25 amino acids was observed in the cDNA-derived sequence of the $M$. sexta PBP (Gyorgyi et al., 1988).

\section{$P B P$ synthesis in $\mathrm{A}$. polyphemus and $\mathrm{M}$ sexta}

Based on the $L$. dispar studies, we made a cursory examination of PBP synthesis in $A$. polyphemus and $M$. sexta for comparison. Antennal extracts of male $A$. polyphemus antennae showed little or no detectable PBP on A-3, but a large amount present on $\mathrm{A} 1$, detected by Coomassie blue staining (Fig. 9a). In vivo labeling of the adult proteins showed that PBP synthesis was occurring at a relatively high rate in the adult stage, between $\mathrm{A} 0$ and $\mathrm{Al}$ (Fig. $9 b$ ).

IVTS of adult (A0) antennal mRNAs and subsequent immunoprecipitations of translated proteins showed similar patterns in $A$. polyphemus, $M$. sexta, and $L$. dispar (Fig. 10). PBP mRNA is apparently very abundant relative to the background of other male antennal mRNAs in all 3 species, as is evident by the abundance of translated PBP in the total translation mixtures. In contrast, there was a total lack of translated PBP
Table 1. Degree of amino acid identity between the $4 \mathrm{~N}$-terminal amino acid sequences (see Fig. 4)

\begin{tabular}{llll} 
& Ldis $_{2}$ & Apol & Msex \\
\hline Ldis $_{1}$ & 0.50 & 0.50 & 0.40 \\
Ldis $_{2}$ & & 0.37 & 0.37 \\
Apol & & & 0.57
\end{tabular}

Numbers are fractions of 1.0 , which would represent $100 \%$ identity. The numbers are not adjusted for property similarities. Ldis ${ }_{1}, \mathrm{Ldis}_{2}$, Apol, and Msex refer to $\mathrm{PBP}_{1}$ and $\mathrm{PBP}_{2}$ of $L$. dispar, and the PBPs of $A$. polyphemus and $M$. sexta, respectively.

in female 4 . polyphemus antennal mRNA translation mixtures, illustrated by the lack of precipitable PBP in the female immunoprecipitation lane. In addition, 2 minor bands, smaller than the major PBPs, were typically observed in immunoprecipitations of translated male antennal mRNAs (Fig. 10). It is not clear what these bands represent, but their mobility pattern was repeatedly observed, and therefore characteristic for each spccics.

\section{Discussion}

PBPs of L. dispar

We have identified 2 olfactory sensilla proteins in the gypsy moth $L$. dispar, which are uniquely associated with male antennae, the principal olfactory organ in these animals. These 2 sensilla proteins comigrate on SDS-PAGE, showing an apparent molecular mass of ca. 15,000 Da. However, they migrate separately on non-SDS-PAGE, suggesting they have different net charges. Both sensilla proteins bind radiolabeled pheromone, and both react positively with antisera generated against the PBP of $A$. polyphemus. Furthermore, both $L$. dispar proteins share sufficient sequence identity with each other and with the PBPs of $A$. polyphemus and $M$. sexta to consider the entire group structural homologs. We therefore have classified these $2 L$. dispar proteins as PBPs. Based on their migration differences on nonSDS-PAGE, we have termed the slower-migrating protein $\mathrm{PBP}_{1}$ and the faster-migrating protein $\mathrm{PBP}_{2}$. The fact that $\mathrm{PBP}_{1}$ and $\mathrm{PBP}_{2}$ share only $50 \%$ identity in their $\mathrm{N}$-terminal regions argues that these represent 2 distinct gene products.

The amount of PBP per antenna can be estimated by comparing the sensilla and antennal lanes in Figure $2 a$. We determined that the total protein concentration of a sensilla homogenate was $45 \mu \mathrm{g} / \mathrm{mg}$ sensilla. Nearly all of this sensilla protein is PBP (Fig. 2a). In Figure 2a, the sensilla lane represents 0.19 $\mathrm{mg}$ sensilla, or ca. $8.5 \mu \mathrm{g}$ total protein, equally distributed between $\mathrm{PBP}_{1}$ and $\mathrm{PBP}_{2}$. These are approximately the same levels of $\mathrm{PBP}_{1}$ and $\mathrm{PBP}_{2}$ observed in the total antennal homogenate lane (Fig. 2a), which represented 3.75 antennae. Thus, a single antenna (ca. $0.9 \mathrm{mg}$ wet weight) contains about $2.2 \mu \mathrm{g}$ of total PBP ( $8.5 \mu \mathrm{g}$ protein divided by 3.75 antennae). 


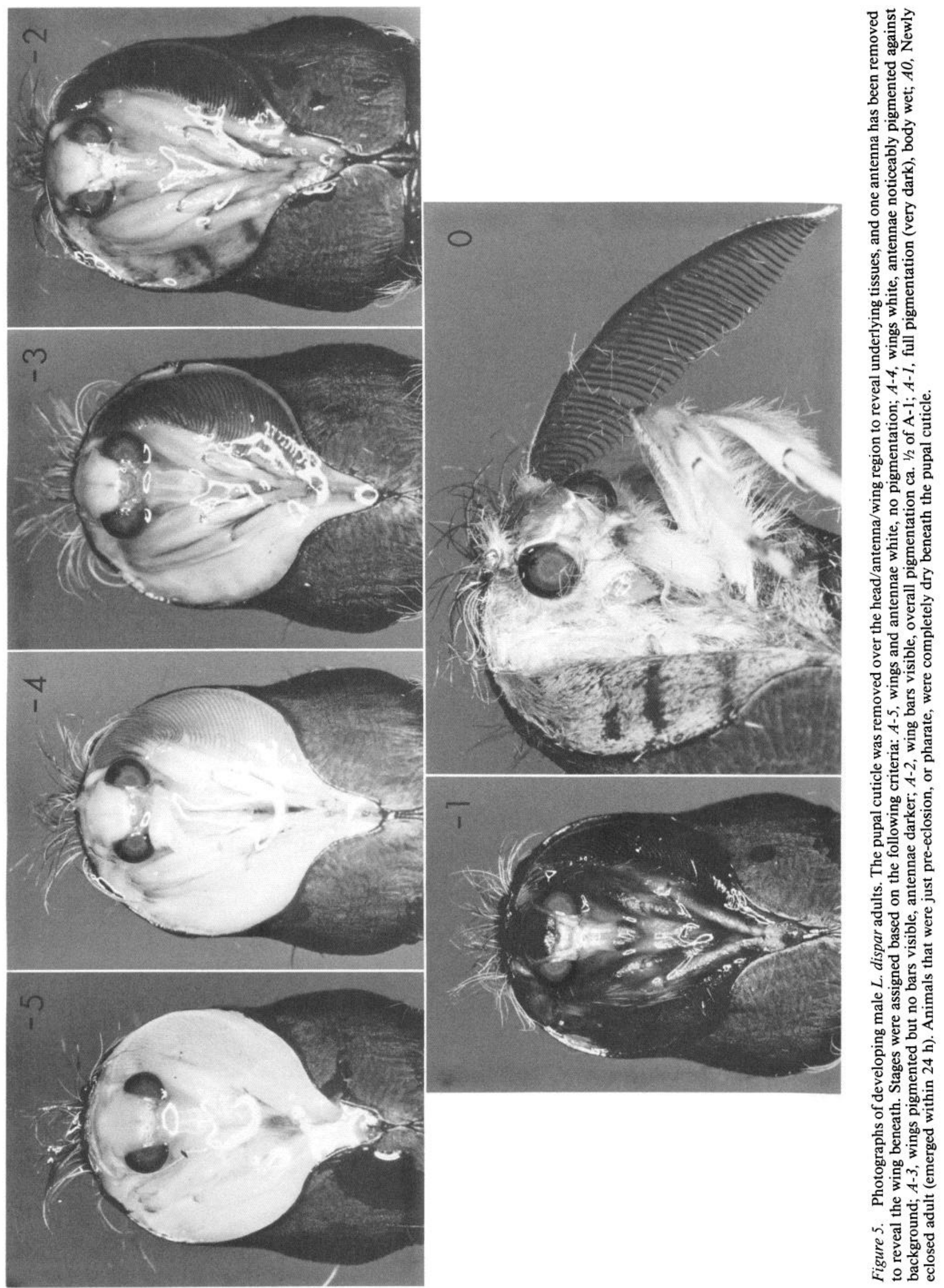




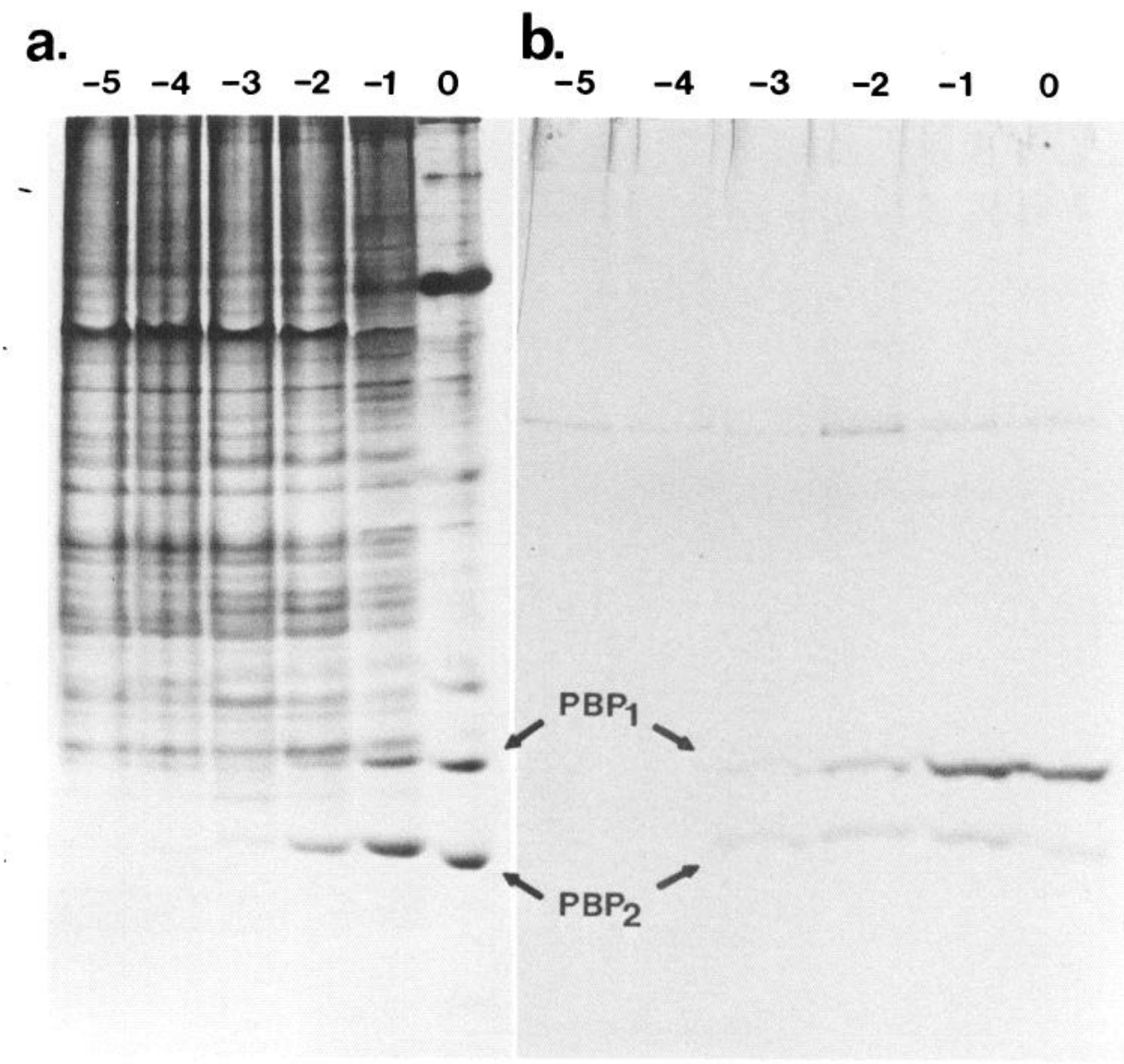

Figure 6. Electrophoretic comparison of male $L$. dispar antennal proteins of different developmental stages, visualized by Coomassie blue $(a)$ and immunostaining $(b)$. Numbers over the lanes indicate the stage of that individual at the time of antennal removal (e.g., -2 refers to stage $A-2$ ). Each lane in $a$ represents 4 antennae pooled from 2 individuals; each lane in $b$ represents 2 antennae from single individuals. The antiserum used in the immunoblot $(b)$ was generated against the $A$. polyphemus PBP and was used at a 1:200 dilution. Protein separation was by nonSDS-PAGE (15\%).

The in situ concentration of total PBP can be estimated based on the amount of PBP per antenna and the assumption that all of the PBP is located within the sensilla lumen (Fig. 1). A single A. polyphemus pheromone-sensitive sensillum is ca. $300 \mu \mathrm{m}$ long with a volume of ca. 10-12 liter (Gnatzy et al., 1984; Vogt et al., 1985). L. dispar sensilla are ca. $200 \mu \mathrm{m}$ long (Scheffler, 1975 ), and thus might have half the volume, or $5 \times 10^{-13}$ liter. In addition, there are ca. 22,000 sensilla per $L$. dispar antenna (Scheffler, 1975). The volume of sensilla lumen per $L$. dispar antenna is thus ca. $1.1 \times 10^{-8}$ liter $\left(5 \times 10^{-13}\right.$ liter per sensillum times 22,000 sensilla per antenna). If we assume that all of the $L$. dispar PBP is associated with the sensillum lumen, then the in situ concentration of total $L$. dispar PBP is $2.2 \mu \mathrm{g} / 1.1 \times 10^{-8}$ liter. This converts to a molar concentration of $13.4 \mathrm{~mm}$ PBP $\left(M W=15,000 \mathrm{Da} ; 2.2 \times 10^{-6} \mathrm{gm}\right.$ PBP per antenna divided by $15,000 \mathrm{gm} / \mathrm{mol}$ divided by $1.1 \times 10^{-8}$ liter). The concentrations of $\mathrm{PBP}_{1}$ and $\mathrm{PBP}_{2}$ would be half this value, or $6.7 \mathrm{mM}$, respectively. This value is very close to the $10 \mathrm{~mm}$ concentration estimated for the PBP of $A$. polyphemus (Klein, 1987).

The PBPs of both $L$. dispar and A. polyphemus appeared to be sex specific in their expression, being absent from female antennae (Fig. 1 and 10; Vogt and Riddiford, 1981b). However, Gyorgyi et al. (1988) have observed that PBP is expressed in female antennae of $M$. sexta, though at a considerably lower level than in male antennae. These authors suggested that the presence of PBP in female $M$. sexta antennae is due to the large number of female olfactory sensilla in this species and that PBP might bind other odorants besides pheromone (Gyorgyi et al., 1988). It is certainly the case that female antennae of $L$. dispar and $A$. polyphemus are very reduced compared with male antennae, possessing comparatively few and very small olfactory sensilla (Boeckh et al., 1960; Scheffler, 1975; Koontz and Schneider, 1987), and that female $M$. sexta antennae possess a comparatively large number of olfactory sensilla relative to males (Sanes and Hildebrand, 1976a; Oland et al., 1988). It is therefore possible that we did not observe PBP in female antennae of $L$. dispar and $A$. polyphemus because there are very few female sensilla and PBP expression was merely too low to detect in these studies.

\section{Expression of PBPs in moth antennae}

Adult antennal development occurs during the pupal stage in Lepidoptera and has been described in depth for $M$. sexta by Sanes and Hildebrand (1976a, b). At the larval-pupal transition $(\mathrm{P} 0)$, the antennal imaginal disks evert and grow into a mass of tissue approximately the size of the adult antennae. At the start of adult antennal development this tissue mass is 2 cell layers thick. The tissue mass then passes through a sequence of morphogenetic events that rapidly result in the adult form (Sanes and Hildebrand, 1976a, b). In L. dispar, adult development takes ca. $11 \mathrm{~d}$ at $27^{\circ} \mathrm{C}$ (Fig. 11). Antennal branches and sensilla are visibly forming during days $\mathrm{P} 2$ and $\mathrm{P} 3$ (R. G. Vogt, unpublished observations). We observed that both $\mathrm{PBP}_{1}$ and $\mathrm{PBP}_{2}$ were first expressed about 3 d prior to adult eclosion (A-3), corresponding to pupal stage P8. Translatable PBP mRNA was detectable at very low levels a day earlier, assayed by IVT. PBP mRNA levels rose to a plateau on $\mathrm{P} 9$ (A-2) where they remained until at least a day into the adult stage. The amount of PBP 
a.

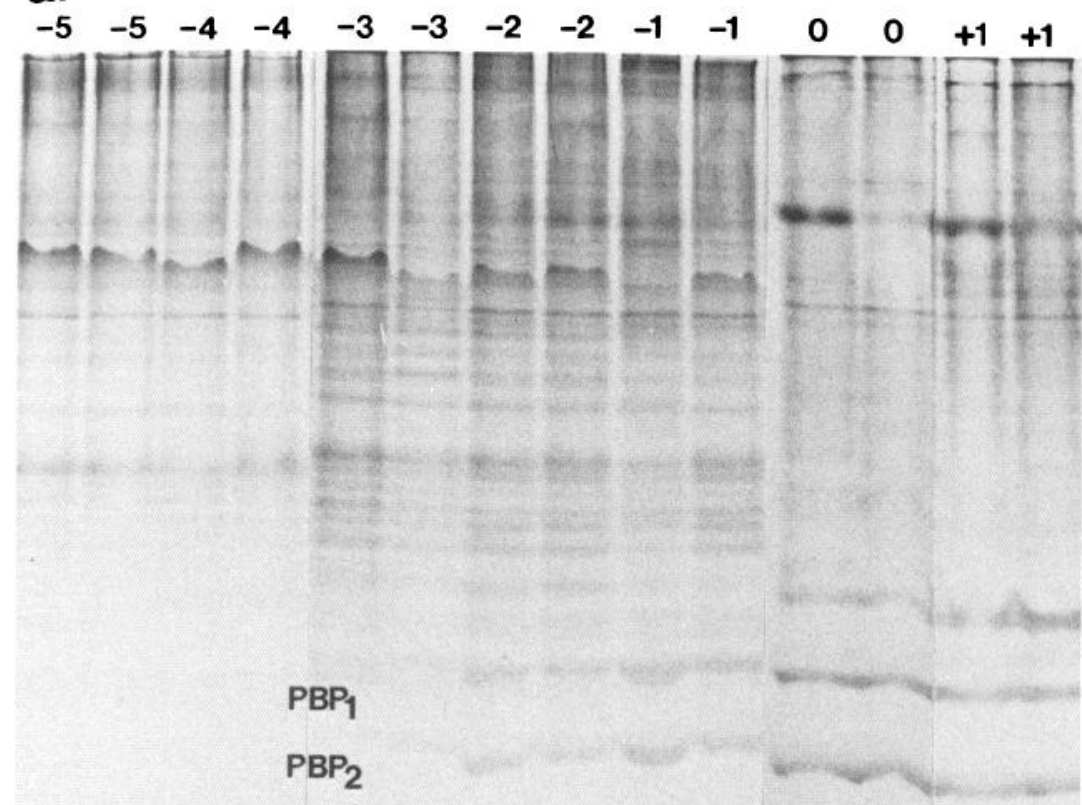

Figure 7. Electrophoretic comparison of total $(a)$ and newly synthesized $(b)$ male $L$. dispar antennal proteins of different developmental stages. Male pupae were injected with ${ }^{35} \mathrm{~S}$-methionine $(33 \mu \mathrm{Ci})$, and $24 \mathrm{hr}$ later antennae were removed, staged, and processed for nonSDS-PAGE (15\%). Proteins were visualized by Coomassie blue staining $(a)$ followed by fluorography $(b)$. Each lane represents protein of one individual, with the stage at the time of antennal removal indicated (e.g., -2 refers to stage A-2). One antennal equivalent was loaded per lane.

b.

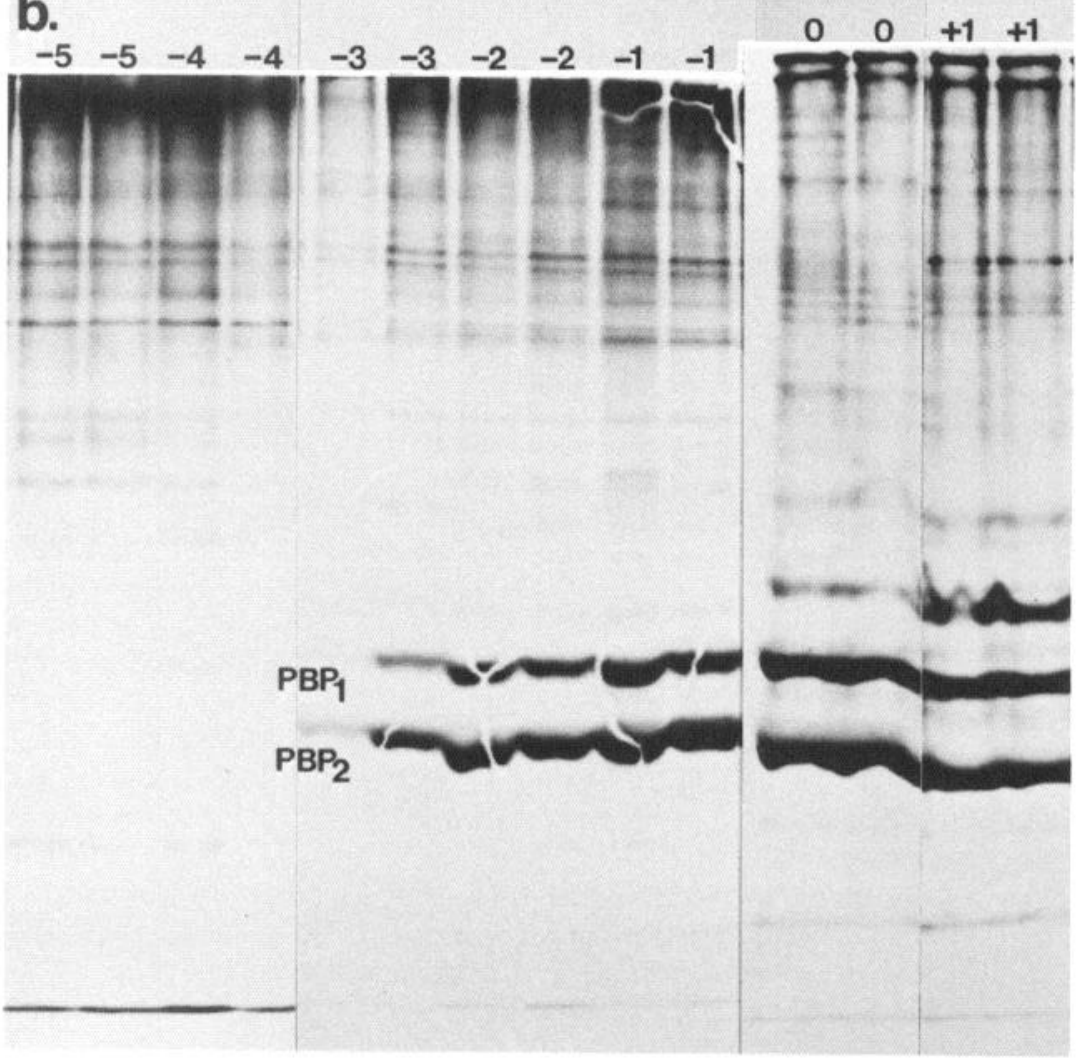

increased to a constant level by P10 (A-1), where it remained at least a day into the adult stage (A1). It is notable that male and female $L$. dispar will readily mate on the day of adult eclosion (A0). These results are summarized in Figure 11. Our observations of PBP expression in A. polyphemus and $M$. sexta were consistent with the $L$. dispar findings, suggesting that this scheme is general.
The observation that the concentration of PBP is held at a constant level while under a constant rate of synthesis suggests that it is under a steady-state rate of turnover. An estimate can be made of this turnover rate. Earlier in this discussion it was estimated that a single antenna contains about $2.2 \mu \mathrm{g}$ of total PBP. The studies illustrated in Figures 6 and 7 suggest that it takes $2 \mathrm{~d}$ to reach this full antennal compliment of $1.1 \mu \mathrm{g}$ of 

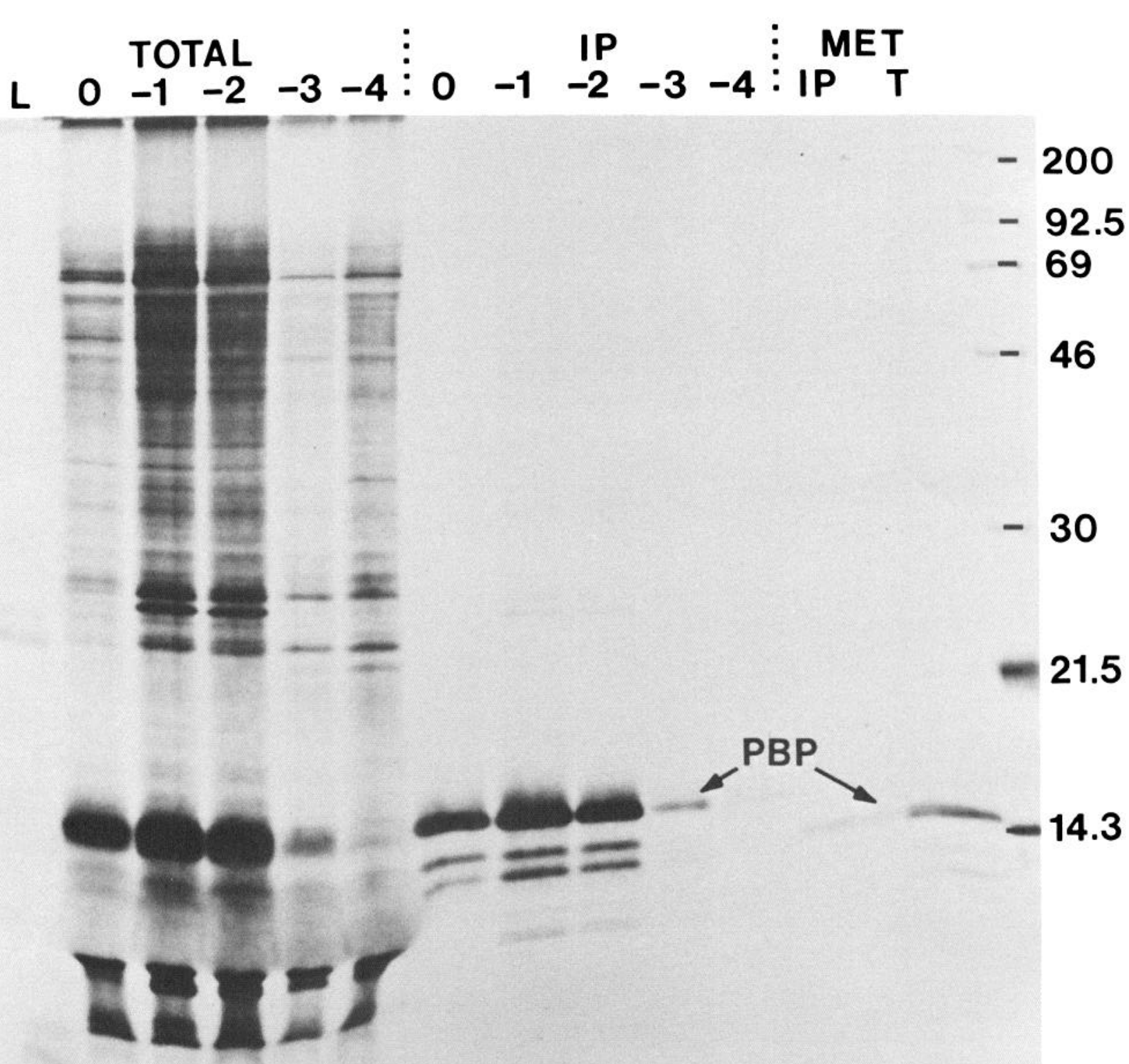

Figure 8. Electrophoretic comparison of in vitro translated antennal mRNAs isolated from different developmental stages. Total, Total in vitro translated proteins from mRNA of male antennal stages A-1 $(-1)$ to $\mathrm{A} 0(0)$ and from lysate control $(L)$. IP, Immunoprecipitated proteins from total in vitro translated mixtures, utilizing combined antisera generated against $L$. dispar $\mathrm{PBP}_{1}$ and $\mathrm{PBP}_{2}$ at $1: 100$ dilution, respectively. For each stage, RNA was isolated from 44 antennae, and tissue equivalent fractions of total and immunoprecipitated proteins were examined. $M E T$, Total $(T)$ and immunoprecipitated $(I P)$ proteins from a homogenate of male antennae, metabolically labeled in vivo with ${ }^{35} \mathrm{~S}$-methionine. Label was injected into A0 males, and antennae were processed $24 \mathrm{hr}$ later. Immunoprecipitation conditions were the same as for the in vitro translated proteins. The blurred region and distortion towards the bottom of the Total lanes was due to the large amount of endogenous hemoglobin present in the lysates. Molecular-weight markers are in kilodalton units.

each PBP. The in vivo labeling study (Fig. 7) suggests that the rate of $\mathrm{PBP}$ synthesis reached a maximum after a day and remained at that maximum. If (1) the full complement of PBP is synthesized in $2 \mathrm{~d}$ and (2) the rate of synthesis remains at this level, but (3) the level of PBP does not continue to increase, then (4) after day A-1 the rate of turnover must match the rate of synthesis. Thus, a steady-state turnover can be estimated to be $1.1 \mu \mathrm{g} \mathrm{PBP}{ }_{1}$ and $\mathrm{PBP}_{2}$, respectively, every $2 \mathrm{~d}$ per antenna, at least from $\mathrm{A}-1$ to $\mathrm{A} 1$.

While the site is not yet confirmed, PBP synthesis most likely occurs in the support cells that surround the neuronal cell bodies at the base of each sensillum (Fig. 1). The PBPs are then presumably exported across the apical membranes of these cells into the sensillum lumen. Coated vesicles and pits, which might 
Figure 9. Electrophoretic comparison of total and newly synthesized male $A$. polyphemus antennal proteins. $a$, Comparison of the total protein of an A-3 $(-3)$ individual with $3 \mathrm{~A} 1$ individuals $(A 1, A 2, A 3)$, visualized by Coomassie blue staining. One antennal equivalent was loaded per lane. The A-3 antennae was staged by allowing its donor to continue its development and eclose, which it did $3 \mathrm{~d}$ later. $b$, Fluorograph of the gel in $a$, representing protein synthesized during the previous $24 \mathrm{hr}$. The Al individuals were injected with ${ }^{35} \mathrm{~S}$ methionine on their respective days of eclosion (A0). The A-3 individual was not injected. The proteins were separated by non-SDS-PAGE (15\%). a.

\section{$\begin{array}{lllllll}-3 & A_{1} & A_{2} & A_{3} & A_{1} & A_{2} & A_{3}\end{array}$}

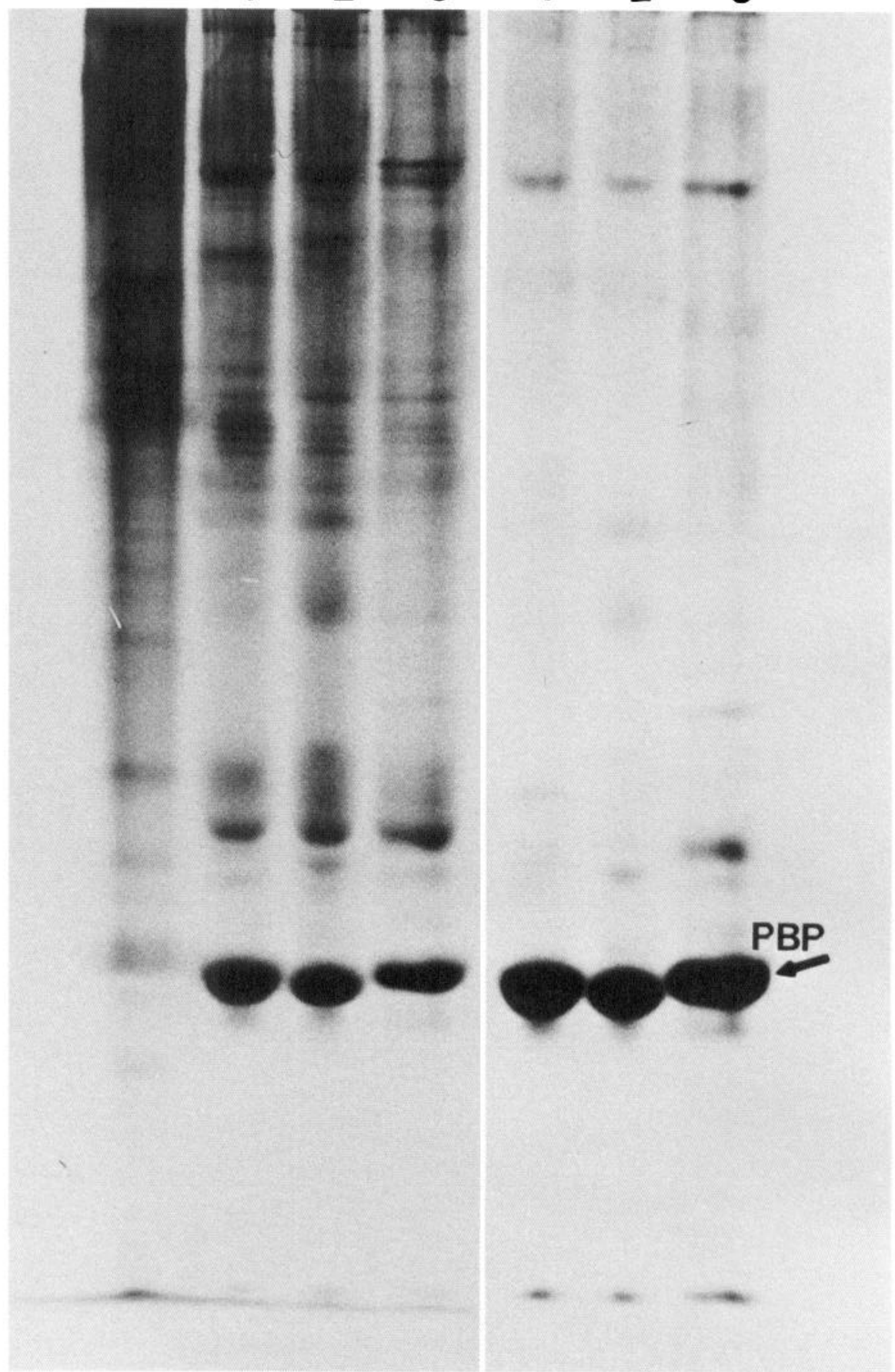

serve as the route of PBP secretion, have been observed associated with these apical membranes (Steinbrecht and Gnatzy, 1984). Assuming that all of the PBP synthesis is restricted to these support cells, the steady-state turnover per sensillum would be $10^{-10} \mathrm{gm}$ PBP per sensillum/ $2 \mathrm{~d}\left(2.2 \times 10^{-6} \mathrm{gm}\right.$ PBP per antenna divided by 22,000 sensilla per antenna), or $2 \times 10^{-12}$ gm PBP/hr $\left(10^{-10}\right.$ gm PBP per $2 \mathrm{~d}$ divided by $48 \mathrm{hr}$ per $\left.2 \mathrm{~d}\right)$. This finally converts to a turnover rate of $8 \times 10^{7}$ molecules $\mathrm{PBP} / \mathrm{hr} /$ sensillum $\left(M W=15,000 \mathrm{Da} ; 2 \times 10^{-12} \mathrm{gm} \mathrm{PBP} / \mathrm{sen}-\right.$ sillum divided by $15,000 \mathrm{gm} / \mathrm{mol}$ multiplied by $6 \times 10^{23} \mathrm{~mol}-$ ecules $/ \mathrm{mol}$ ). The turnover rates of $\mathrm{PBP}_{1}$ and $\mathrm{PBP}_{2}$ would each be half this value, or $4 \times 10^{7}$ molecules $/ \mathrm{hr} /$ sensillum, respectively.

This high rate of turnover is curious because it is of an extracellular protein that exists in a somewhat closed space, the sensillum lumen. Turnover implies that the protein is exported and imported across the same cell membranes (Fig. 1). It is normal for insect epithelium to export and import large amounts 


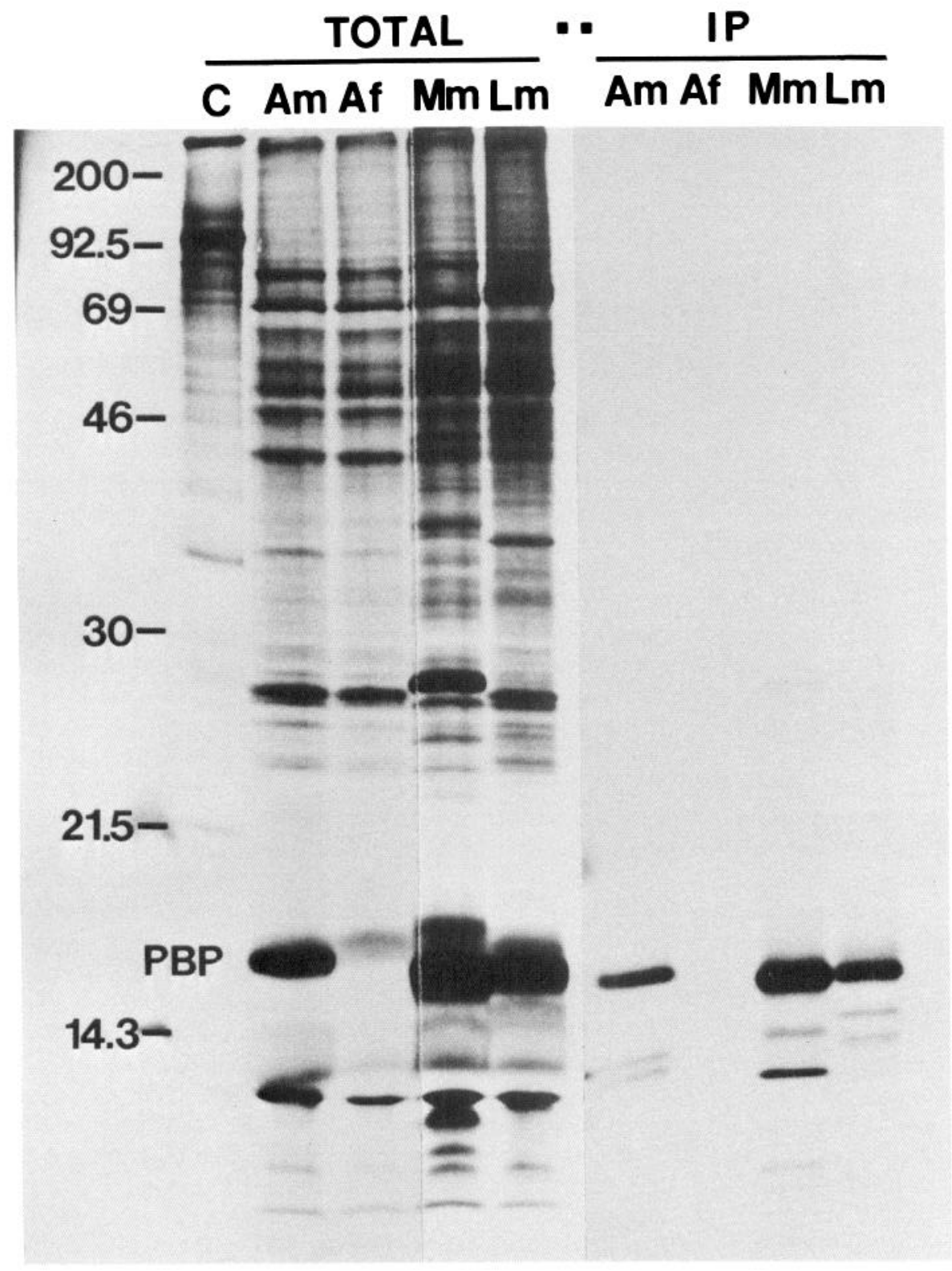

Figure 10. Electrophoretic comparison of in vitro translated proteins from antennal mRNAs of adult (A0) male and female $A$.polyphemus ( $A m$ and $A f$ ), male $M$. sexta $(M m)$ and male $L$. dispar $(\mathrm{Lm})$. Total and immunoprecipitated (IP) proteins are shown. Antisera used in the immunoprecipitations were generated against the PBPs of the respective species. Proteins were separated by SDS-PAGE (15\%). Molecular weightmarkers are in kilodalton units.

of cuticle protein during the molt cycle, secreting protein to build cuticle, and then resorbing partially degraded cuticle proteins to be recycled into the next stage cuticle (Hepburn, 1985). However, these 2 processes are separated in time in the case of cuticle production. In the sensilla, secretion and apparent resorption of PBP seem to be occurring simultaneously. Do these processes occur in discretely different regions of cell membrane, or do they even occur within the same cell? Do the cells resorb intact or degraded PBP? Is the site of PBP degradation in the sensillum lumen or within the support cells? Does recycling of PBP contribute in any way to the dynamic properties of these sensilla?

Our observations indicate that $L$. dispar PBP expression is initiated ca. $3 \mathrm{~d}$ before adult eclosion. Similarly, $M$. sexta PBP (Gyorgyi et al., 1988), pheromone-degrading enzyme (Rybczynski et al., 1989), and male olfactory specific antigen (MOSA) (Hishinuma et al., 1988a, b) were also first observed about $3 \mathrm{~d}$ before adult eclosion, even though $M$. sexta adult development requires $20 \mathrm{~d}$ (Sanes and Hildebrand, 1976a) compared with the $11 \mathrm{~d}$ of $L$. dispar. This suggests that the final molecular maturation of the olfactory sensilla is coordinated relative to adult eclosion. Schwartz and Truman (1983) have suggested that many of the events occurring late in adult development are coordinated by falling levels of the steroid hormone 20 -hydroxy ecdysone, and this may prove to be the case for molecular maturation of the olfactory system as well.

\section{The function of PBPS}

We have previously suggested a model for pheromone reception in which (1) pheromone enters a sensillum via a pore through the cuticle wall, (2) pheromone becomes solubilized in the lumen by interacting with PBP, (3) PBP-solubilized pheromone migrates through the lumen until it encounters either a membraneassociated receptor protein or an inactivating enzyme (Vogt et al., 1985; Vogt, 1987). Two key points in this scheme are (1) rapid pheromone degradation by specific enzymes and (2) the 


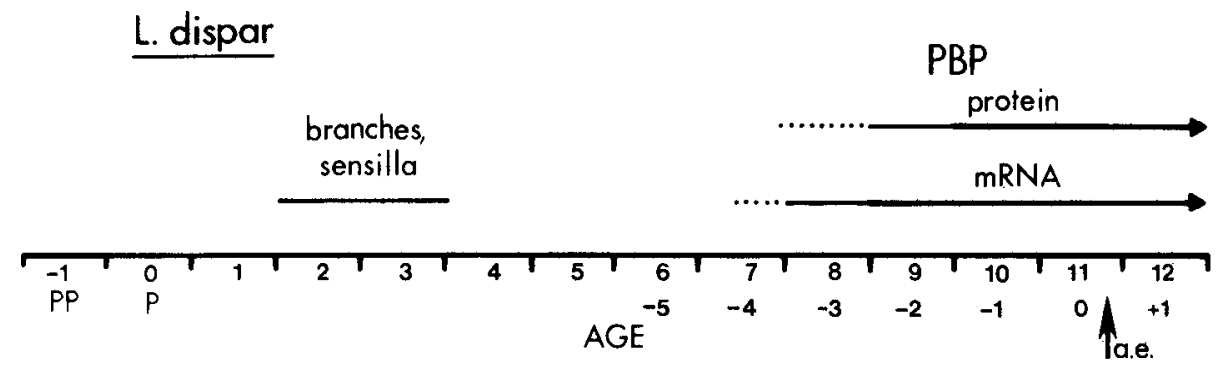

Figure 11. Summary of PBP expression during antennal development. The axis represents age, both relative to pupal eclosion (upper numbers, -1 to 12) and adult eclosion (lower numbers, -5 to +1$). P P$ and $P$, days of prepupal and pupal selection, respectively; a.e. (at $a r$ row), time of adult eclosion. need for pheromone molecules to be solubilized (Kaissling, 1986; Vogt, 1987). Pheromone-degrading enzymes have been described in A. polyphemus (Vogt and Riddiford, 1981b; Vogt et al., 1985), $M$. sexta (Rybczynski et al., 1989), and $L$. dispar (Prestwich et al., 1989). The $A$. polyphemus and $M$. sexta enzymes are an esterase and an aldehyde oxidase, respectively, which are uniquely associated with the antennae and present in the lumen of the pheromone-sensitive sensilla. These enzymes degrade sex pheromone sufficiently fast in vitro to suggest they are responsible for rapid stimulus inactivation. A similarly rapid odorant degradation process has been described in the olfactory organ of a lobster (Trapido-Rosenthal et al., 1987). Thus, rapid enzymatic inactivation of olfactory signal appears to be general, at least in arthropods.

The need for odorant molecules to be water soluble also appears to be general. While fully aquatic animals smell watersoluble odorants such as amino acids and purines, terrestrial animals smell volatile, hydrophobic odorants. Olfactory specific proteins that can enhance the solubility of hydrophobic odorants have been described in vertebrates (Pelosi et al., 1982; Pevsner et al., 1985, 1986; Lee et al., 1987) and invertebrates (Vogt and Riddiford, 1981a; Chase and Tolloczko, 1985; Chase, 1986; Gyorgyi et al., 1988). Both the rat (Pevsner et al., 1988a) and insect (Vogt, 1987; Gyorgyi et al., 1988) odorant binding proteins have been suggested to trap or solubilize odorants, aiding in their transport to membrane-associated receptor proteins. In the land snail, the olfactory epithelium is located on the tipsurface of each tentacle, surrounding the eye. Epithelial glands secrete large quantities of proteins that apparently act to wet the surface of the epithelium hygroscopically, and may otherwise aid in the capture of volatile odorants (Chase and Tolloczko, 1985; Chase, 1986). It may be that odorant binding proteins represent a terrestrial adaptation, evolved to deal with volatile odorants. Gyorgyi et al. (1988) have found that the vertebrate and insect odorant binding proteins are not related, based on comparison of their cDNA-derived full-length sequences (Gyorgyi et al., 1988; Pevsner et al., 1988b). This suggests that if these odorant binding proteins were terrestrial adaptations, they evolved independently and represent a convergence in evolution.

Two genetically distinct PBPs are expressed in $L$. dispar antennae, in contrast to other species we have examined where only a single PBP is expressed. These species include $A$. polyphemus (Vogt and Riddiford, 1981b), Antheraea pernyi (Vogt and Riddiford, 1981a), $M$. sexta (Gyorgyi et al., 1988), and Heliothis virescens, Orgyia pseudotsuga, and Hyalophora cecropia (R. G. Vogt, unpublished observations). Furthermore, the 2 L. dispar PBPs apparently bind the sex pheromone disparlure with different affinities. Both $(+)$ and $(-)$ disparlure remained associated with $\mathrm{PBP}_{2}$ to an equivalent and substantially greater extent than to $\mathrm{PBP}_{1}$ through electrophoretic separation (Fig. 3).
There are several hypotheses to account both for the existence of $2 \mathrm{~L}$. dispar PBPs and for the difference in apparent disparlure binding affinities for $\mathrm{PBP}_{1}$ and $\mathrm{PBP}_{2}$. First, there may be 2 sensilla types, equally represented and containing $\mathrm{PBP}_{1}$ and $\mathrm{PBP}_{2}$, respectively. Second, $\mathrm{PBP}_{1}$ and $\mathrm{PBP}_{2}$ might coexist in the same sensilla and through different pheromone affinities affect the dynamic response of the hair. The lower-affinity $\mathrm{PBP}_{1}$ might either increase the capacity of pheromone within the sensillum or influence the partitioning and mobility of pheromone within the sensillum. Third, the presence of $\mathrm{PBP}_{1}$ and its apparent low affinity for disparlure may predict an additional pheromone in L. dispar, one with considerably different structure than disparlure. The identity table (Table 1) indicates that $\mathrm{PBP}_{1}$ shares more identity with the $A$. polyphemus and $M$. sexta PBPs than does $\mathrm{PBP}_{2}$. The pheromones of $A$. polyphemus and $M$. sexta are very similar long-chain hydrocarbons with polar functional end groups (Kochansky et al., 1975; Starratt et al., 1979; Doolittle et al., 1988), in contrast to the very different structure of the epoxide disparlure (Bierl et al., 1970). Perhaps the presence of $\mathrm{PBP}_{1}$ suggests an additional $L$. dispar pheromone component structurally more similar to the $A$. polyphemus or $M$. sexta pheromones than to disparlure. A fourth, but unlikely, hypothesis is that $\mathrm{PBP}_{1}$ binds the degraded product of disparlure. Homogenates of whole $L$. dispar antennae readily convert the epoxide disparlure to a diol (Prestwich et al., 1989), while sensilla isolated under our conditions do not (R. G. Vogt, unpublished observations). When we attempted the binding study illustrated in Figure 3 utilizing whole antennal homogenates under conditions where epoxide degradation was rapid, we observed no radiolabeling of either $P B P$, suggesting that the diol was not binding. A similar lack of PBP-pheromone product association was previously observed in the $A$. polyphemus system (de Kramer and Hemberger, 1987).

Many of the issues raised by these studies can be addressed at the histological level utilizing appropriate nucleic acid and antibody probes. These issues include the cellular localization, sex specificity, and sensillar distribution of PBP expression, as well as the subcellular sites of PBP turnover and recycling. It is becoming increasingly clear that the insect odorant binding proteins represent a family of proteins that have a specific role in the sexual behavior of these animals. Considering the central role olfaction plays in reproduction in these animals, it is difficult to imagine that the molecular components of this system have been selected to play other than dynamic roles in this process.

There are clear cross-phyla parallels in the olfactory system at both the anatomical and molecular levels. An anatomy of primary olfactory neurons terminating in glomerular synapses within an olfactory bulblike structure exists in vertebrates (Shepherd, 1972), insects (Schneiderman et al., 1982; Ernst and Boeckh 1983; Koontz and Schneider, 1987), and molluscs (Chase and Tolloczko, 1986). A biochemistry of documented and candidate 
odorant binding proteins exists within the same groups (Chase, 1986; Vogt, 1987; Pevsner et al., 1988a). Insects provide an outstanding model system for understanding the principals underlying olfactory function. The moth olfactory organ is particularly, well suited to molecular level studies because of its considerable size and accessibility and its highly focused function of detecting and monitoring sex pheromone. Testing the roles the molecular components play requires an ability to manipulate these components, and the development of such an ability seems paramount to the comprehension of this system. Nevertheless, in light of the role that odor detection plays in the sexual behavior of these animals, insight into the molecular basis of insect olfaction contributes directly to our understanding of the role the PNS has in coordinating complex behavior.

\section{References}

Aebersold, R. H., D. B. Teplow, L. E. Hood, and S. B. H. Kent (1986) Electroblotting onto activated glass. High efficiency preparation of proteins from analytical sodium dodecyl sulfate-polyacrylamide gels for direct sequence analysis. J. Biol. Chem. 261: 4229-4238.

Ames, G. F.-L. (1974) Resolution of bacterial proteins by polyacrylamide gel electrophoresis on slabs. J. Biol. Chem. 249: 634-644.

Bierl, B. A., M. Beroza, and C. W. Collier (1970) Potent sex attractant of the gypsy moth: Its isolation, identification and synthesis. Science 170: 87-89.

Boeckh, J., K. E. Kaissling, and D. Schneider (1960) Sensillen und Bau der Antennengeissel von Telea polyphemus (Verleiche mit weiteren Saturniden: Antheraea, Platasamia, und Philosamia). Zool. J. Anat. 78: 559-584.

Chamberlain, J. P. (1979) Fluorographic detection of radioactivity in polyacrylamide gels with the water-soluble fluor, sodium salicylate. Anal. Biochem. 98: 132-135.

Chase, R. (1986) Lessons from snail tentacles. Chem. Sens. 11:411426.

Chase, R., and B. Tolloczko (1985) Secretory glands of the snail tentacle and their relation to the olfactory organ (Mollusca, Gastropoda). Zoomorphol. 105: 60-67.

Chase, R., and B. Tolloczko (1986) Synaptic glomeruli in the olfactory system of a snail, Achatina fulica. Cell Tissue Res. 246: 567-573.

de Kramer, J. J., and J. Hemberger (1987) The neurobiology of pheromone reception. In Pheromone Biochemistry, G. D. Prestwich and G. L. Blomquist, eds., pp. 433-472, Academic, Orlando, FL.

Doolittle, R. F. (1986) Of URFs and ORFs: A Primer on How to Analyze Derived Amino Acid Sequences, University Science Books, Mill Valley, CA.

Doolittle, R. E., J. H. Tumlinson, E. R. Mitchell, and M. M. Brennean (1988) The spectroscopic identification and stereoselective synthesis of the sex pheromone blend of the tobacco hornworm Manduca sexta. Abstract AGRO 38, Third Chemical Congress of North America, Toronto, June 5-10, 1988.

Ernst, K. D., and J. Boeckh (1983) A neuroanatomical study on the organization of the central antennal pathways in insects. III. Neuroanatomical characterization of physiologically defincd responsc typcs of deutocerebral neurons in Periplaneta americana. Cell Tissue Res. 229: $1-22$.

Forbush, E. H., and C. H. Fernald (1896) The Gypsy Moth. Porthetria dispar (Linn.) A report of the work of destroying the insect in the Commonwealth of Massachusetts, together with an account of its history and habits both in Massachusetts and Europe. Massachusetts State Board of Agriculture, Boston.

Gnatzy, W., W. Mohren, and R. A. Steinbrecht (1984) Pheromone receptors in Bombyx mori and Antheraea pernyi. II. Morphometric analysis. Cell Tissue Res. 235: 35-42.

Gyorgyi, T. K., A. J. Roby-Shemkovitz, and M. R. Lerner (1988) Characterization and $\mathrm{CDNA}$ cloning of the pheromone binding protein from the tobacco hornworm, Manduca sexta: A tissue-specific, devclopmentally regulated protein. Proc. Natl. Acad. Sci. USA 85: 9851-9855.

Hansen, K. (1984) Discrimination and production of disparlure enantiomers by the gypsy moth and the nun moth. Physiol. Entomol. 9: 9-18.
Hepburn, H. R. (1985) Structure of the integument. In Comprehensive Insect Physiology Biochemistry and Pharmacology, Vol. 3, G. A. Kerkut and L. I. Gilbert, eds., pp. 1-58, Pergamon, Oxford, UK.

Hishinuma, A., S. Hockfield, R. McKay, and J. G. Hildebrand (1988a) Monoclonal antibodies reveal cell-type-specific antigens in the sexually dimorphic olfactory system of Manduca sexta. I. Generation of monoclonal antibodies and partial characterization of the antigens. J. Neurosci. 8: 296-307.

Hishinuma, A., S. Hockfield, R. McKay, and J. G. Hildebrand (1988b) Monoclonal antibodies reveal cell-type-specific antigens in the sexually dimorphic olfactory system of Manduca sexta. II. Expression of antigens during postembryonic development. J. Neurosci. 8: 308315.

Kaissling, K. E. (1986) Chemo-electrical transduction in insect olfactory receptors. Annu. Rev. Neurosci. 9: 121-145.

Klein, U. (1987) Sensillum-lymph proteins from antennal olfactory hairs of the moth Antheraea polyphemus (Saturniidae). Insect Biochem. 17: 1193-1204.

Klein, U., and T. A. Keil (1984) Dendritic membrane from insect olfactory hairs: Isolation method and electron microscopic observations. Cell. Mol. Neurobiol. 4: 385-396.

Kochansky, J., J. Tette, E. F. Taschenberg, R. T. Carde, K. E. Kaissling, and W. L. Roelofs (1975) Sex pheromone of the moth Antheraea polyphemus. J. Insect Physiol. 21: 1977-1983.

Koontz, M. A., and D. Schneider (1987) Sexual dimorphism in neuronal projections from the antennae of silk moths (Bombyx mori, Antheraea polyphemus) and the gypsy moth (Lymantria dispar). Cell Tissue Res. 249: 39-50.

Laemmli, U. K. (1970) Cleavage of structural proteins during the assembly of the head of bacteriophage T4. Nature 227: 680-685.

Lee, K.-H., R. G. Wells, and R. R. Reed (1987) Isolation of an olfactory cDNA: Similarity to retinol-binding protein suggests a role in olfaction. Science 235: 1053-1056.

Maniatis, T., E. F. Fritsch, and J. Sambrook (1982) Molecular Cloning. A Laboratory Manual, Cold Spring Harbor Laboratory, Cold Spring Harbor, NY.

Oland, L. A., L. P. Tolbert, and K. L. Mossman (1988) Radiationinduced reduction of the glial population during development disrupts the formation of olfactory glomeruli in an insect. J. Neurosci. 8: 353367.

Pelosi, P., N. E. Baldaccini, and A. M. Pisanelli (1982) Identification of a specific olfactory receptor for 2-isobutyl-3-methoxypyrazine. Biochem. J. 201: 245-248.

Pevsner, J., R. R. Trifiletti, S. M. Strittmatter, and S. H. Snyder (1985) Isolation and characterization of an olfactory receptor protein for odorant pyrazines. Proc. Natl. Acad. Sci. USA 82: 3050-3054.

Pevsner, J., P. B. Sklar, and S. H. Snyder (1986) Odorant-binding protein: Localization to nasal glands and secretions. Proc. Natl. Acad. Sci. USA 83: 4942-4946.

Pevsner, J., P. M. Hwang, P. B. Sklar, J. C. Venable, and S. H. Snyder (1988a) Odorant-binding protein and its mRNA are localized to lateral nasal gland implying a carrier function. Proc. Natl. Acad. Sci. USA 85: 2383-2387.

Pevsner, J., R. R. Reed, P. G. Feinstein, and S. H. Snyder (1988b) Molecular cloning of odorant-binding protein: Member of a ligand carrier family. Science 241: 336-339.

Preiss, R., and E. Kramer (1983) Stabilization of altitude and specd in tethered flying gypsy moth males: Influence of $(+)$ and $(-)$-disparlure. Physiol. Entomol. 8: 55-68.

Prestwich, G. D. (1987) Chemical studies of pheromone reception and catabolism. In Pheromone Biochemistry, G. D. Prestwich and G. L. Blomquist, eds., pp. 473-527, Academic, Orlando, FL.

Prestwich, G. D., S. McG. Graham, J.-W. Kuo, and R. G. Vogt (1989) Tritium-labeled enantiomers of disparlure: Synthesis and in vitro metabolism. J. Am. Chem. Soc. 111: 636-642.

Riddiford, L. M. (1982) Changes in translatable mRNAs during the larval-pupal transformation of the epidermis of the tobacco hornworm. Dev, Biol. 92: 330-342

Rybczynski, R., J. Reagan, and M. R. Lerner (1989) A pheromonedegrading aldehyde oxidase in the antennae of the moth Manduca sexta. J. Neurosci. 9: 1341-1353.

Sanes, J. R., and J. G. Hildebrand (1976a) Structure and development of antennae in a moth, Manduca sexta. Dev. Biol. 51: 282-299.

Sanes, J. R., and J. G. Hildebrand (1976b) Origin and morphogenesis of sensory neurons in an insect antenna. Dev. Biol. 51: 300-319. 
Scheffler, H. J. (1975) Der Bau der Antennen bei WZ- und ZZ-Intersexen des Schwammspinners Lymantria dispar L. (Insecta, Lepidoptera). Z. Morph. Tiere 80: 203-227.

Schneider, D., W. A. Kafka, M. Beroza, and B. A. Bierl (1977) Odor receptor responses of male gypsy and nun moths (Lepidoptera, Lymantriidae) to disparlure and its analogs. J. Comp. Physiol. 113: 115.

Schneiderman, A., S. G. Matsumoto, and J. G. Hildebrand (1982) Trans-sexually grafted antennae influence development of sexually dimorphic neurons in moth brain. Nature 298: 844-846.

Schwartz, L. M., and J. W. Truman (1983) Hormonal control of rates of metamorphic development in the tobacco hornworm Manduca sexta. Dev. Biol. 99: 103-114.

Shepherd, G. (1972) Synaptic organization of the mammalian olfactory bulb. Physiol. Rev. 52: 864-917.

South, R. (1907) The Moths of the British Isles, 4th ed., 1961, Frederick Warne, London.

Starratt, A. M., K. H. Dahm, N. Allen, J. G. Hildebrand, T. L. Payne, and $H$. Roller (1979) Bombykal, a sex pheromone of the sphinx moth, Manduca sexta. Z. Naturforsch. 34C: 9-12.

Steinbrecht, R. A. (1987) Functional morphology of pheromonc-sensitive sensilla. In Pheromone Biochemistry, G. D. Prestwich and G. L. Blomquist, eds., pp. 353-384, Academic, Orlando, FL.

Steinbrecht, R. A., and W. Gnatzy (1984) Pheromone receptors in Bombyx mori and Antheraea pernyi. I. Reconstruction of the cellular organization of the sensilla trichodea. Cell Tissue Res. 235: 25-34.

Towbin, H., T. Staehelin, and J. Gordon (1979) Electrophoretic transfer of proteins from polyacrylamide gels to nitrocellulose sheets: Procedure and some applications. Proc. Natl. Acad. Sci. USA 76: 4350 4354.

Trapido-Rosenthal, H. G., W. E. S. Carr, and R. A. Gleeson (1987)
Biochemistry of an olfactory purinergic system: Dephosphorylation of excitatory nucleotides and uptake of adenosine. J. Neurochem. 49: $1174-1182$.

Vogt, R. G. (1984) The Biochemical Design of Sex Pheromone Reception in the Wild Silk Moth Antheraea polyphemus. Ph.D. Dissertation, University of Washington, Seattle.

Vogt, R. G. (1987) The molecular basis of pheromone reception: Its influence on behavior. In Pheromone Biochemistry, G. D. Prestwich and G. L. Blomquist, eds., pp. 385-431, Academic, Orlando, FL.

Vogt, R. G., and G. D. Prestwich (1987) Variation in olfactory proteins, evolvable elements encoding insect behavior. Ann. NY Acad. Sci. 510: 689-691.

Vogt, R. G., and L. M. Riddiford (1981a) Pheromone deactivation by antennal proteins of Lepidoptera. In Regulation of Insect Development and Behaviour, F. Sehnal, A. Zabza, J. J. Menn, and B. Cymborowski, eds., pp. 955-967, Polytechnic University of Wroclaw Press, Wroclaw, Poland.

Vogt, R. G., and L. M. Riddiford (1981b) Pheromone binding and inactivation by moth antennae. Nature 293: 161-163.

Vogt, R. G., and L. M. Riddiford (1986) Pheromone reception: A kinetic equilibrium. In Mechanisms in Insect Olfaction, T. L. Payne, M. C. Birch, and C. E. J. Kennedy, eds., pp. 201-208, Oxford U.P., New York.

Vogt, R. G., L. M. Riddiford, and G. D. Prestwich (1985) Kinetic properties of a sex pheromone-degrading enzyme: The sensillar esterase of Antheraea polyphemus. Proc. Natl. Acad. Sci. USA 82:88278831.

Vogt, R. G., G. D. Prestwich, and L. M. Riddiford (1988) Sex pheromone receptor proteins, visualization using a radiolabeled photoaffinity analog. J. Biol. Chem. 263: 3952-3959. 